Journal of Marine Systems

January 2016, Volume 153, Pages 25-41

http://dx.doi.org/10.1016/i.jmarsys.2015.09.002

http://archimer.ifremer.fr/doc/00280/39124/

(C) 2015 Elsevier B.V. All rights reserved.

\title{
Probabilistic approach of water residence time and connectivity using Markov Chains with application to tidal embayments
}

\author{
Bacher Cedric ${ }^{1,{ }^{*}}$, Filgueira R. ${ }^{2}$, Guyondet T. ${ }^{2}$
}

${ }^{1}$ French Institute for Sea Research (IFREMER), BP70, 29280 Plouzané, France

${ }^{2}$ Department of Fisheries and Oceans, Gulf Fisheries Centre, Science Branch, P.O. Box 5030, Moncton, NB E1C 9B6, Canada

*Corresponding author : Cedric Bacher, email address : cedric.bacher@ifremer.fr

\begin{abstract}
:
Markov Chain analysis was recently proposed to assess the time scales and preferential pathways into biological or physical networks by computing residence time, first passage time, rates of transfer between nodes and number of passages in a node. We propose to adapt an algorithm already published for simple systems to physical systems described with a high resolution hydrodynamic model. The method is applied to bays and estuaries on the Eastern Coast of Canada for their interest in shellfish aquaculture. Current velocities have been computed by using a 2 dimensional grid of elements and circulation patterns were summarized by averaging Eulerian flows between adjacent elements. Flows and volumes allow computing probabilities of transition between elements and to assess the average time needed by virtual particles to move from one element to another, the rate of transfer between two elements, and the average residence time of each system. We also combined transfer rates and times to assess the main pathways of virtual particles released in farmed areas and the potential influence of farmed areas on other areas. We suggest that Markov chain is complementary to other sets of ecological indicators proposed to analyse the interactions between farmed areas - e.g. depletion index, carrying capacity assessment. Markov Chain has several advantages with respect to the estimation of connectivity between pair of sites. It makes possible to estimate transfer rates and times at once in a very quick and efficient way, without the need to perform long term simulations of particle or tracer concentration.
\end{abstract}

\section{Highlights}

- We defined residence time in a very general stochastic framework - We computed the probability of particles transition with hydrodynamic models - We estimated the pathways of particles with a quick and general algorithm - We derived connectivity from particles pathways in the context of aquaculture - On this basis, we compared mixing scales of 3 embayments

Keywords : Transfer time, transfer rate, residual flow, indicators, aquaculture, hydrodynamics 


\section{Introduction}

Physical exchanges play a key role in marine ecosystems. In many cases, the transport and the mixing of particulate and dissolved matters control the dynamics and the main characteristics of marine abiotic and biotic components. Monsen et al. (2002) stress the importance of assessing the time scale related to physical processes, and quote a number of studies dealing with biogeochemical processing, thermal stratification in lakes, mineralization of organic matter, primary production, harmful algae blooms, structure and functioning of microbial loop where physical time scales play a major role. Looking at possible control of eutrophication by benthic communities, Officer et al. (1982), Cloern (1982), Hily (1991) clearly identified residence time as a key parameter to the interactions between biological processes. They were followed by Dame and Prins (1998) who established that carrying capacity for suspension feeding bivalves is a function of primary production turnover rate, bivalve filtration rate and water residence time. The assessment of carrying capacity gave birth to a number of modelling studies where the water renewal time of bays and estuaries were precisely quantified (Koutitonsky et al., 2004; Guyondet et al., 2005). Along with physical time scales, pathways of substances transported by water movement were also investigated in a number of recent studies. Ghezzo et al. (2015) defines connectivity as the physical dispersion of particles which are passive or which interact with their environment (e.g. larvae corresponding to the pelagic phase during the life cycle of organisms). Such studies are motivated by the need to identify the potential effect of living (e.g. pathogens) or non living (e.g. pollutant) substances on the growth, survival and production of species of interest (e.g. keystone species, cultivated species) as well as the spatial interactions between distant populations having a pelagic life stage. This is no surprise that many authors argue that quantities like water renewal times and connectivity contribute to the assessment of health of aquatic systems and are a prerequisite to the development of indicators for management (Ribbe et al., 2008; Abdlerhman, 2005; Adams et al., 2012; Filgueira et al., in press; Cucco and Umgiesser, 2006; Dumas et al. 2012; Guyondet et al., 2013; Huang, 2007; Miller and McPherson, 1991; Mudge et al., 2008; Treml et al., 2008; Thomas et al., 2012).

The main concepts of mixing time scales can be found in Bolin and Rodhe (1973), Zimmerman (1976), Takeoka (1984) and Monsen et al. (2002), but the vocabulary remains very diverse - e.g. retention time, flushing time, e-flushing time, residence time, local residence time, average residence time, integral residence time, age, turnover time, exposure time, transit time, local effect time. All these terms refer to the time that a single or an amount 
of particles stay within a domain or, alternatively, the time needed to leave the domain. Definitions and methods used to measure the time scale also account for spatial scale and size. Some authors consider the time for a particle to cross a spatial domain (e.g. bay, estuary), others measure the time that a particle in one region of a domain will take to reach another region or to exit the whole domain. In other cases, a global indicator of the water renewal time for the whole domain is sufficient. For instance, residence time (RT) is the time until a water parcel at a specified location leaves a given domain, which can be an estuary, a bay or a portion of the open ocean. Local residence time (LRT) is the time period for concentration of a uniformly distributed tracer to drop below a threshold value at a specific location within the embayment. It is sometimes called the e-flushing time when the concentration follows an exponential law and the threshold is equal to $1 / \mathrm{e}, \mathrm{e}=2.718$ (Dumas et al., 2012). The average of local residence time over an embayment is the integral residence time (IRT, Koutitonsky et al., 2004). The IRT is useful to compare coastal ecosystems studies, while the LRT allows to analyse the structure of water mixing within an ecosystem and the potential response of that ecosystem to perturbations - e.g. human activities (Koutitonsky et al., 2004).

Though there are a few examples of the estimation of mixing time scales on the basis of data (e.g. salinity) and simple equations (Zimmerman, 1976; Mudge et al., 2008; Miller and McPherson,1991; Abdelrhman, 2007), pathways of particles are usually not observable and models are therefore needed when the spatial patterns of local time characteristics are investigated (Ribbe et al., 2008). On the basis of three-dimensional, depth or laterallyaveraged two-dimensional circulation models, Lagrangian (Adams et al., 2012; Basterretxea et al., 2012; Braunschweig et al., 2003; Brooks et al., 1999; Ghezzo et al., 2015; Monsen et al., 2002; Orfila et al., 2005; Safak et al., 2015; Tartinville et al., 1997; Thomas et al., 2012; Thompson et al., 2002; Wijeratne and Rydberg, 2007) or Eulerian (Abdelrhman, 2005; Cucco and Umgiesser, 2006; De Brye et al., 2012; Delhez and Deleersnijder, 2002; Döös and Engqvist, 2007; Dumas et al., 2012; Gourgue et al., 2007; Gustafsson and Bendtsen, 2007; Guyondet et al., 2013; Huang, 2007; Koutitonsky et al., 2004; Plus et al., 2009; Ribbe et al., 2008; Shen and Wang, 2007; Treml et al., 2008; Yuan et al., 2007) methods allow to track the passage of passive tracers or single particles.

As mentioned above, different time scales have been assessed in these case studies using one definition or another. In addition, some authors moved a step forward by computing the connectivity between areas within the domain of interest (Basterretxea et al., 2012; Ghezzo et al., 2015; Thomas et al., 2012; Treml et al., 2008). To evaluate the optimal size and locations of marine protected areas (MPA) near SW Mallorca Island, Basterretxea et al. (2012) assessed 
the connectivity among near-shore habitats and showed that the drifting distance of fish larvae was consistent with the MPA design. For this purpose the domain of interest is divided into a number of spatial boxes and simulations of particles drift are run with a series of initial conditions and during a period corresponding to the larval duration. Connectivity is defined as the number of particles arriving into box $\mathrm{i}$ from box $\mathrm{j}$ by the end of period divided by the number of particles initially released in box j. Thompson et al. (2002) built transition probabilities in a similar way. Using a 3D tidal circulation model of a macrotidal area (Passamaquoddy bay), they divided the bay into 15 boxes and estimated transition using stochastic particle tracking. They also introduced Markov Chain theory and assessed some properties of the system - e.g. first passage time, probability to stay in a box or move to another box after a given time. Leguerrier et al. (2006) developed an algorithm based on Markov Chain theory and computed residence time, first passage time, rates of transfer between boxes and number of passages in a box using transition matrix. As an illustration, they applied this algorithm to a simple food web and the same physical system as Thompson et al. (2002) and showed how to analyse preferential pathways of matter into simple systems. We propose to adapt the algorithm from Leguerrier et al. (2006) to physical systems described with a high resolution hydrodynamic model. Current velocities have been computed by using a 2 dimensional grid of elements and circulation patterns were summarized by averaging Eulerian flows between adjacent elements. Flows and element volumes allow to compute probabilities of transition between elements. Instead of running simulations of particles movement, we applied Leguerrier's algorithm to the resulting transition matrix and we were able to easily compute some characteristics of the system - e.g. average time needed by virtual particles to move from one element to another, rate of transfer between 2 elements, residence time.

This study relies upon previous works on hydrodynamic modelling on 3 bays and estuaries in Eastern Canada. The objectives were the following:

1) Extend the Markov chain to $2 \mathrm{D}$ systems to compute residence time, transfer rate, transfer time

2) Compute connectivity in relation with aquaculture issues

3) Compare ecosystem properties 


\section{Material and Methods}

\subsection{Study sites}

Three sites have been recently investigated on the Eastern Coast of Canada for their interest in shellfish aquaculture, a sector which plays an important economic role in this region. Tracadie Bay is a bar-built embayment located on the north shore of PEI $\left(46^{\circ} 23^{\prime} \mathrm{N} 62^{\circ} 59^{\prime} \mathrm{W}\right.$, Fig. 1). It is the smallest $\left(19.4 \mathrm{~km}^{2}, 44 \times 10^{6} \mathrm{~m}^{3}\right.$, Table 1) and shallowest (maximum depth 7 m, Fig. 1) bay considered in this study, and is open to the Gulf of St. Lawrence through two channels, a main one located on the West side of the bay and a breach in the central part of the sand barrier which formed in December 2009 after several storms touched ground on PEI. Winter Harbour is a sub-basin located at the southwest side of Tracadie Bay where a small river drains $\left(\approx 1 \mathrm{~m}^{3} \mathrm{~s}^{-1}\right)$. The complexity of the embayment morphology, expressed as the ratio between the coastline length and the root square of the area, indicates that Tracadie Bay is the least complex of the three systems (Table 1). The tidal range is $0.3-1.0 \mathrm{~m}$ and the instantaneous exchange of bay with the offshore is up to $868 \mathrm{~m}^{3} \mathrm{~s}^{-1}$, which results in a renewal time of 8.4 days (Table 1 ).

The Richibucto Estuary is a bar-built river estuary located in southeastern New Brunswick along the Northumberland Strait $\left(46^{\circ} 41^{\prime} \mathrm{N} 64^{\circ} 50^{\prime} \mathrm{W}\right.$, Fig. 1). It is the intermediate-sized embayment of this study $\left(33.2 \mathrm{~km}^{2}, 58 \times 10^{6} \mathrm{~m}^{3}\right.$, Table 1$)$, with maximum depths of $10 \mathrm{~m}$ in the central channel (Fig. 1). The estuary is open to the Northumberland Strait through two permanent channels and a narrow breach (width 25-30 m and depth $1.2 \mathrm{~m}$ ) in the center of the sand dunes located east of the main channel. The system can be divided into three areas: North Arm, Central Harbour and Baie du Village. Two rivers discharge into the estuary. The Richibucto River $\left(\approx 24 \mathrm{~m}^{3} \mathrm{~s}^{-1}\right)$ runs into the Central Harbour and St. Charles River $\left(\approx 5 \mathrm{~m}^{3} \mathrm{~s}^{-1}\right)$ into the North Arm. These three areas result in a more complex morphology compared to Tracadie Bay (Table 1). The tidal range is 0.3-1.3 $\mathrm{m}$ and the instantaneous exchange of bay with the offshore is up to $2040 \mathrm{~m}^{3} \mathrm{~s}^{-1}$, resulting in an average renewal time of 6.6 days (Table 1). This renewal time is the shortest of the three studied systems. It should be noted that this value differs significantly among the three main areas of the system, with the North Arm and Baie du Village areas having larger renewal times than the Central Harbour.

The Malpeque Bay system is a bar-built embayment located on the north shore of PEI $\left(46^{\circ} 32^{\prime} \mathrm{N} 63^{\circ} 48^{\prime} \mathrm{W}\right.$, Fig. 1). It is the largest system of this study, covering a surface area of $223.6 \mathrm{~km}^{2}$ and a total volume of $629.5 \times 10^{6} \mathrm{~m}^{3}$ (Table 1), with maximum depth of $12 \mathrm{~m}$ (Fig. 1). The bay is open to the Gulf of St. Lawrence through three permanent channels, the main 
one located in the northeastern part of the system and two smaller ones on the northwestern part. Malpeque is composed of several sub-basins and an intricate river system. Grand River, which discharges into the most southern part of the system, is the main river in terms of discharge $\left(\approx 1 \mathrm{~m}^{3} \mathrm{~s}^{-1}\right)$. The multiple sub-basins and the morphology formed by the river system results in a morphological complexity similar to Richibucto Estuary (Table 1). The tidal range is $0.3-1.1 \mathrm{~m}$ and the instantaneous exchange of bay with the offshore is up to $10 \times 10^{3} \mathrm{~m}^{3} \mathrm{~s}^{-1}$, which results in a renewal time of 10.3 days, the longest of the three systems (Table 1).

\subsection{Hydrodynamic modelling}

A finite element model was developed for the 3 study sites using the RMA suite of models (Resource Modelling Associates, http://ikingrma.iinet.net.au). RMA-10 solves the Reynolds form of the Navier-Stokes equations for momentum, the continuity equation and a convection-diffusion equation for transport of heat, salinity and any dissolved or suspended matter. It uses a Smagorinsky scheme (Smagorinsky 1963) to estimate horizontal eddy diffusivities. This model has been used to reproduce water circulation in response to tidal, meteorological (wind and atmospheric pressure) and river forcing. The implementation of the hydrodynamic model in the 3 bays relies upon an unstructured grid made of triangular elements which accounts for the variability of the bathymetry and the morphology of each bay. Details on implementation, parameterization and calibration of the model have been reported in previous works (Filgueira et al., 2014; Guyondet et al. 2013; Filgueira et al., in press; for Tracadie, Richibucto and Malpeque respectively).

The advection-dispersion scheme of the validated numerical model was first used to estimate the spatial distribution of the $e$-folding water renewal time over the entire system (Filgueira et al., 2013). We adopted the definition of local residence time (LRT) found in Abdelrhman (2005), Koutitonsky et al. (2004) and Guyondet et al. (2013). LRT is defined as the time for concentration of a uniformly distributed tracer to drop below a threshold value at a specific location. The model reproduces the spatio-temporal evolution of bay waters that are marked by a passive tracer (concentration $C=1$ at time $t=0$ ), as they are being renewed by the tracerfree waters $(C=0)$ of the river and Gulf of St. Lawrence. Assuming an exponential decrease in concentration owing to mixing, a location is considered as renewed when the tracer concentration falls below $1 / e$ of the initial value. The time needed to reach this point is defined as the water renewal time. Note that LRT is equivalent to the e-flushing time used by Dumas et al. (2012). Also note that, when the concentration decline is following an 
exponential law, LRT is exactly equal to the average time needed by a tracer to leave the system.

\subsection{Computation of average flows}

For each node, RMA provides values for three quantities at each time step: water speed in the $\mathrm{x}$-direction, water speed in the y-direction and water depth. The volumetric flow through the edge of 2 adjacent elements is calculated by multiplying the net velocity by the crosssectional area. RMA provides a time series for water velocity and depth at each node, and the protocol described above can be applied to each time step. The volumetric flows for all time steps are averaged as a daily mean for each link following a first order upwind scheme. The error of this averaged flow scheme is kept to a minimum if the spatial and temporal variation of the concentration of a conservative tracer remains small for each element and time step. The procedure is fully described by Filgueira et al. (2012) and detailed in Appendix A.

\subsection{Markov transition matrix}

Computation of residence time, transfer time and transfer rate is based on the algorithm developed by Leguerrier et al. (2006). The main assumptions of this approach are i) the probability of finding the particle in any given region depends only on its location at the previous time, and ii) this probability does not change over time at some appropriate time scale. This is the basis of Markov Chain theory, with a considerable amount of literature dedicated to the analysis of the properties of such systems. We apply exactly the same algorithm as Leguerrier et al. (2006) to a physical system made of $N$ triangle elements. Input data are the average flows $\left(\mathrm{m}^{3} / \mathrm{d}\right)$ between all pairs of elements and element volumes obtained by the averaging procedure described by Filgueira et al. (2012) and mentioned above.

We note $F_{i j}$ the flow going from element $j$ to element $i$. The last column $(j=N+1)$ of the $\boldsymbol{F}=$ $\left(F_{i j}\right)$ matrix corresponds to the inputs from the boundary, and the last row $(i=N+1)$ to the outputs from the elements which are at the boundary. By definition, the total output from any element equals the total input to this element. Noting $V_{i}$ the volume of element $i$, the probability that a particle which is in element $j$ at time $t$ moves to element $i$ during one time step $\Delta t$ is equal to:

$$
p_{i j}=\frac{F_{i j}}{V_{j}} \cdot \Delta t \text { for } i \in[1, N+1] \text { and } j \in[1, N]
$$

Probability for a particle that is in $i$ to stay in $i$ during one time step is given by: 


$$
p_{i i}=1-\sum_{\substack{k \neq i \\ k \in[1, N+1]}} p_{k i} \text { for } i \in[1, N] \quad \text { Eq. } 2
$$

Time step $\Delta t$ is chosen as half the minimum of turnover times computed for all elements so that each term of the matrix is positive and less than 1. Matrix $P$ is completed by adding the "system outside" column: a column of zeros, with 1 for the last element which is an absorbing element (which means that particles reaching this element will stay and not re-enter the system). This matrix is stochastic since the sum of each of its column is equal to one (Bailey, 1964). It is the transition matrix of a Markovian process, in which the random variable is the concentration $C$ of a tracer in each element. Given the initial vector of concentration $C_{0}$ of a particle in the system, concentration at time $t+\Delta t$ is equal to:

$$
C_{t+1}=P \cdot C_{t} \quad \text { Eq. } 3
$$

hence

$$
C_{t+1}=P^{t} \cdot C_{0} \quad \text { Eq. } 4
$$

The vector of concentration $C_{t+1}$ only depends on concentration at time $t$ and not of the former states, which is the characteristic of the Markov property (Bailey, 1964). $C_{t}$ is always less than 1 , and hence represents the probability distribution of a unit of matter within the system. As time is incremented, one can then compute the probability distribution of a unit of matter, or, as Thompson et al. (2002) did, compute the probability that a particle stays in a element in which it was present at time $t=0$, the probability that a particle is absorbed by the outside element, or the probability that a particle moves from one element to another for the first time during time $t$.

\subsection{Calculation of indices from a Markov transition probability matrix}

Let us define $A_{i, t}$ as the event for a particle to be in element $i$ at time $t \geq 0$. The conditional probability $a_{i, j, t}=P\left(A_{i, t} / A_{j, 0}\right)$ is the probability to be in element $i$ at time $t$, assuming that the particle was in element $j$ at time 0 . Equation (4) shows that $a_{i, j, t}$ corresponds to the component $\left(P^{t}\right)_{i, j}$ of the matrix $P^{t}$, where $P$ is the transition matrix.

The generator function associated to the probability distribution $\left\{a_{i, j, t}, t \in\{1,2, \cdots\}\right\}$ is defined as:

$$
\alpha_{i, j}(s)=\sum_{k=0}^{\infty} a_{i, j, k} \cdot s^{k} \quad \text { Eq. } 5
$$

It can be shown that: 


$$
\alpha_{i, j}(s)=(I-s \cdot P)_{i, j}^{-1} \quad \text { Eq. } 6
$$

where $I$ is the identity matrix.

Note that the above definition of $A_{i, t}$ does not specify whether the particle has reached element $i$ before $t$. We now define $B_{i, t}$ the event of being for the first time in element $i$ at time $t>0$ and $B_{i, j, t}$ the subset of $B_{i, t}$ corresponding to the event of being in $j$ at time 0 . The probability of such an event is given as a conditional probability $b_{i, j, t}=P\left(B_{i, t} / A_{j, 0}\right)$. We define the average passage time $T_{i j}$ as the expectation of the random variable $t$ associated to the probability distribution $b_{i, j, t}$ and the transfer rate $R_{i j}$ as the average of the probability distribution $b_{i, j, t}$.

Using the generator functions $\beta_{i, j, t}(s)=\sum_{k=0}^{\infty} b_{i, j, k} \cdot s^{k}$, we can write:

$$
T_{i j}=\frac{d \gamma_{i, j}}{d s}(s=1) \quad \text { Eq. } 7
$$

and

$$
R_{i j}=\gamma_{i, j}(s=1) \quad \text { Eq. } 8
$$

Leguerrier et al. (2006) showed that $\gamma_{i, j}(s)$ can be derived from $\alpha_{i, j}(s)$ :

$$
\left\{\begin{array}{l}
\gamma_{i, i}=-\frac{1}{\alpha_{i, i}} \\
\gamma_{i, j}=-\frac{\alpha_{i, j}}{\alpha_{i, i}}
\end{array} \quad \text { Eq. } 9\right.
$$

The algorithm is therefore based on the following steps:

- computation of the matrix of transition probability $P$

- computation of $\alpha_{i, j}(s)$ for $s$ close to 1 by calculating $(I-s \cdot P)^{-1}$

- computation of $\gamma_{i, j}(s)$ for s close to 1 with equation (9)

- $\quad$ computing $T_{i j}$ and $R_{i j}$ with equations (7) and (8)

\subsection{Special cases of transfer rates and times}

Residence time is defined as the average time needed by a particle, being initially in a given element, to leave the system. It is a particular case of the transfer time between a given element and the element which represents the external world and is an absorbing state in the 
Markov Chain matrix of transition probabilities. The residence time is called Markov Chain based Residence Time (MCRT) in the rest of the text.

For each system, we have also selected a source element and mapped the transfer rates (TR) and times (TT) between this source element and all other elements of the systems. This application is used to illustrate the type of results automatically produced by the Markov Chain based algorithm and also to highlight some characteristics of water mixing in the systems. Since the calculations are made all at once, the choice of any element and the mapping of TR and TT can be made on demand. Here, we have chosen a single source element at the entrance of each bay or estuary as a complement to the previous results of residence times.

\subsection{Links between elements: connectivity indicators}

Transfer time (TT) and transfer rate (TR) are defined for any couple of elements and can be used to assess their physical links. Such descriptions are much simpler than dynamical simulations and can be used to screen the structure of water flows and potential connectivity between geographic zones within the same system. When transfer rates and times are computed for one source element and any other element in the area, results can be displayed as 2 maps showing the connections between elements. In addition, transfer rates and times are computed for all $N^{2}$ pairs of elements and the distribution of values allows comparing the 3 bays time scales and intensity of mixing.

A more complete application of the use of TR and TT is proposed with respect to aquaculture extension. It follows the lines of a companion study on Malpeque bay which addressed some spatial planning issue regarding the increase in aquaculture acreage and the potential conflicts linked to other marine activities, aboriginal rights and stakeholder interests as well as impacts between actual and projected new leases (Filgueira et al., in press). Such impacts are related to the filtration of organic matter (e.g. phytoplankton) by cultivated filter-feeders. Filtration would deplete the concentration of organic matter and affect the availability of organic matter in the vicinity of aquaculture areas and the growth of filter feeders in distant areas. Several methods have been proposed to assess the intensity of food depletion, and the calculation of TR and TT is complementary of more elaborate computations based on ecosystem models. The main pathways of matter among leased areas have been identified by analyzing transfer time $\left(T_{i j}\right)$ and transfer rate $\left(R_{i j}\right)$ from element $j$ to element $i$ for all the pairs of elements $(i, j)$ that belong to any actual or projected leased area. Potential interactions between leases were defined through the identification of $(i, j)$ pairs with high connectivity - e.g $T_{i j}<20$ days and 
$R_{i j}>0.1$, suggesting that the time that is required for a particle released in element $j$ to reach element $i$ is shorter than 20 days and the average amount of matter that reaches element $i$ is above $10 \%$. The number of $(i, j)$ pairs that meet the thresholds were counted and the number of successful connections was turned into a percentage of connections between two leased areas. The main results showed that current leases have an elevated potential of influencing projected leases while the projected leases are not significantly connected to the current leases and a strong connectivity exist among projected leases.

Shellfish aquaculture is present in our 3 study sites and, as for Malpeque bay, concerns have been raised on the impacts of aquaculture and ecosystem carrying capacity. To illustrate some potential use of TR and TT we first identified the set of elements $j$ belonging to aquaculture areas. We computed $T_{i j}$ and $R_{i j}$ between $j$ and all other elements $i$ of the bay or estuary. For each element $i$ outside the aquaculture area, we calculated

$T_{i}^{\min }=\min _{j}\left(T_{i j}\right)$

and

$R_{i}^{\max }=\max _{j}\left(R_{i j}\right)$

and mapped the results. High $T_{i}^{\text {min }}$ values correspond to elements which particles emitted from any aquaculture area would take a long time to reach. Low $R_{i}^{\max }$ indicate that a small fraction of particles emitted from aquaculture areas would reach element $i$. Therefore, elements with low $R_{i}^{\max }$ and high $T_{i}^{\min }$ would be less connected to (and influenced by) aquaculture area. The combination of the 2 indices corresponding maps highlight the regions which have low connectivity with the aquaculture areas. Note that other statistics could also be computed to give a more accurate picture of connectivity between cultivated and not cultivated areas, but the example is sufficient to illustrate the interest of such quantities.

\section{Results}

\subsection{Comparison of RMA and averaged flow simulation for Malpeque}

The agreement between both hydrodynamic (RMA) and averaged flow models has been evaluated by comparing the spatial and temporal outcomes of both models generated under the same initial and boundary conditions. Several numerical conservative experiments changing these conditions have been carried out in order to strengthen the validation process. An example of one of these numerical experiments for Malpeque is presented in Figure 2. In 
this example, the initial tracer concentration in the model domain has been set up as 0 units of tracer per $\mathrm{m}^{3}$, and a constant tracer concentration of 100 units per $\mathrm{m}^{3}$ has been prescribed at the boundary. The spatial tracer distribution in the model domain after 90 days of simulation is presented in Figure $2 \mathrm{a}$ and $2 \mathrm{~b}$ for the hydrodynamic and averaged flow models, respectively. Given that the hydrodynamic model can deliver outcomes at a shorter temporal resolution than the averaged flow model, which is constructed with daily water exchange coefficients, the outcomes of the hydrodynamic model have been averaged for a period of 24 hours in Figure 2a. This averaging is required to make a meaningful comparison of the performance of both models. The different temporal resolution could explain the mismatch of both simulations in some areas of the model domain. The effect of the different temporal resolution is clearly observed when the total mass of tracer in the model domain is plotted through time (Fig. 2c). Despite the fact that both models are able to provide similar mean trends through time, the hydrodynamic model can provide information about tidal effects, which is missing in the averaged flow model (Fig. 2c). The good agreement in mean spatial and temporal patterns suggests that the averaged flow model can be used to accurately estimate conservative tracer dispersion within a temporal resolution of days.

\subsection{Comparison of average flows for the 3 sites}

In order to complete the description of the 3 study sites the hydrodynamic model results were used to compute the root-mean square (RMS) current $\left(V_{R M S}\right)$ at each node $i$ of the domains, using the equation:

$V_{R M S}(i)=\frac{1}{N_{T}} \sum_{t=1}^{N_{T}} \sqrt{u_{i, t}^{2}+v_{i, t}^{2}} \quad$ Eq. 10

where $N_{T}$ is the total number of time steps in the simulation and $u_{i, t}, v_{i, t}$ are the current velocities at node $i$ and time $t$ in $\mathrm{x}$ and y directions, respectively.

Maps of the spatial distribution of $V_{R M S}$ in each of the 3 study sites are presented in Fig. 3. Moreover, the mean $V_{R M S}$ value over each bay or estuary is reported in Table 1 for comparison purposes.

All 3 systems present maximum flows at their respective inlets where tidal water exchange occurs through restricted cross-sections (Fig. 3). Passed the inlets the 3 systems behave somewhat distinctly. 
In Malpeque and Tracadie mean flows decrease rapidly towards the inner bay area. In Tracadie bay especially, short narrow channels connect the inlets to the deeper basin where currents fall below $0.03 \mathrm{~m} \mathrm{~s}^{-1}$ (Fig. 3a). In Malpeque bay the channel from the main inlet divides in two branches where currents remain relatively strong (up to $0.3 \mathrm{~m} \mathrm{~s}^{-1}$ ) and then drop to $0.06-0.09 \mathrm{~m} \mathrm{~s}^{-1}$ in the central part of the bay (Fig. 3b). Narrow channels leading to Grand River and around Lennox island exhibit slightly higher flows (up to $0.2 \mathrm{~m} \mathrm{~s}^{-1}$ ) while the peripheral areas of Darnley Basin, Marchwater and the southern head of the bay experience the weakest currents $\left(<0.03 \mathrm{~m} \mathrm{~s}^{-1}\right)$.

In Richibucto the entrance channel does not lead to a much wider area as in the two other systems (Fig. 3c). The estuary rather consists in branching channels, resulting in a more complex system with a slightly stronger tidal forcing (Table 1). The main channel leads to the Richibucto River concentrating the tidal flow in such a way that mean flow speeds do not substantially decrease before reaching the upstream limit of the model domain $\left(0.2-0.4 \mathrm{~m} \mathrm{~s}^{-}\right.$

$\left.{ }^{1}\right)$. Secondary channels also exhibit intense flows in their narrowest sections $\left(0.15-0.3 \mathrm{~m} \mathrm{~s}^{-1}\right)$. Overall, the main differences between these 3 systems lie within their respective inner morphology as reflected by the increasing complexity from Tracadie to Malpeque to Richibucto and which also translate into increasing spatially averaged flows (Table 1).

\subsection{Comparison of residence time: RMA (LRT) and Markov Chain algorithm for the 3 sites}

Local Residence Time (LRT) and Markov Chain based Residence time (MCRT) measure similar quantities and the comparison between maps of LRT and MCRT is an indirect way to evaluate the effect of flow averaging on mixing scales. At first sight, LRT and MCRT give very similar results (Fig. 4). As expected, renewal times are always higher in the upper arms of the estuary than in the downstream areas. In Tracadie bay, renewal time is generally lower than 40 days (Fig. 4a, b) with a range similar to Richibucto (Fig. 4c, d). On the other hand, Malpeque exhibits higher values, up to 60 days and more (Fig. 4e, f).

Spatial patterns of LRT and MCRT look very similar, but some differences are visible in some areas of each system. In Tracadie bay, the LRT is almost zero in the vicinity of the most western inlet, as opposed to MCRT which shows a less pronounced gradient in the same area. For practical reasons (very low averaged exchange flows), some elements have been removed in the MCRT calculation in the most western arm of Tracadie bay, which explains the absence of values in this area. For Malpeque, the largest differences between the 2 calculations occur in the central region of the bay. In this area, LRT shows a steeper gradient between 40 and ca. 
15 days, which contrasts with MCRT values around 30 days and a MCRT gradient more pronounced near the main entrance of the bay. Another difference is noticed in the most southern part of the bay, where LRT gives higher values (60 days and more) than MCRT (range of values between 50 and 60 days). In Richibucto estuary, some differences occur in the upper section of the larger arm. In this region, LRT values lie around 20 days, as opposed to MCRT values which are closer to 15 days.

\subsection{Examples of transfer rates and times from one element (entrance of the bay) - for} the 3 sites

We have chosen a single source element at the entrance of each bay or estuary as a complement to the previous results of residence times. For this case study, TT represents the average time for a particle to enter the bay or estuary and reach any location (target element). For instance maximum values lie ca. 50 days in Richibucto and Tracadie bay, while TT can reach 80 days in Malpeque for the most upstream sections of the bay (Fig. 5). With no surprise, TT are low near the source element, but there is a large section of each bay or estuary where TT remains lower than 20 days. The TR maps provide additional information on the main pathways. Values lie between 0 (no transfer between the source and the target elements) and 1 (a particle would reach the target with a probability equal to 1 ). Therefore particles can take a long time to reach a target element with a low probability - which is the case of most of the target elements distant from the source. An interesting case is shown in Tracadie bay. High TR and medium TT link the second outlet of the bay to the one where the source element is located, which shows that there is some recirculation at the mouth of the bay.

\subsection{Computation and maps of connectivity with respect to existing aquaculture leases for} the 3 sites.

In Tracadie Bay and Richibucto estuary, $T_{i}^{m i n}$ values are always lower than 30 days (Fig. 6 b, f), while $T_{i}^{\text {min }}$ can reach 60 days in Malpeque bay (Fig. 6d). As expected, regions close to aquaculture areas have low $T_{i}^{\min }$ and high $R_{i}^{\max }$. Most interesting is the fact that some regions distant from aquaculture area are also characterized by low $T_{i}^{\min }$ and high $R_{i}^{\max }$. This is the case of the central channel of Richibucto estuary which is probably most influenced by existing aquaculture sites. Only a small region of Tracadie bay is not much influenced by aquaculture, with low $R_{i}^{\max }$ and $T_{i}^{\min }$ being visible near the most western outlet of the bay. 
Similarly, the southwestern arm of Malpeque bay is isolated from the influence of aquaculture sites.

\section{Discussion}

\subsection{Evaluation of Markov Chain method}

In ecology, the primary use of Markov models has focused on modelling the succession of communities or spatial distribution of metapopulations (Tucker and Anand, 2004; Hill et al., 2004; Logofet and Lesnaya 2000; Benabdellah et al. 2003; Moilanen, 2004). In such applications, transition probabilities correspond to the probability of replacement of one individual, species or functional group by another. Observed successions over time allow to compute transition probabilities which are used to compute several features of the ecosystem dynamics. Transition probabilities can also be interpreted as stochastic processes related to the capacity of a species or functional group to occupy a given location - e.g. colonisation, disturbance, replacement, persistence (Hill et al., 2004). Markov chains allow to derive the long term distribution of individuals/species/groups, the rate of successional change (turnover time), the time needed to come back to a state that has been previously left (recurrence time), the response of community to perturbation (Hill et al., 2004). Markov chain has also been applied to the cycling of matter in an ecological network (Leguerrier et al., 2006). First passage time and number of cycles within the network relate to another field of ecological studies based on network analysis (Patten and Higashi, 1995). The issues generally raised in all these applications are dealing with i) first order stochasticity assumption, ii) estimation of transition probabilities, iii) stationarity of the transition matrix.

The main assumption of Markov models is that the state of the system at time $t+1$ depends only on the state at time t. It means that Markov models are not appropriate in the cases where the history or the memory of the system cannot be neglected - e.g. ontogeny. The Markov framework also describes the processes involved in the system dynamics as stochastic. In the application by Thompson et al. (2002), probabilities capture the transport of particles due to deterministic (e.g. tidal currents) and stochastic (e.g. random dispersion) processes. In our case, it may be surprising, at first sight, that deterministic flows result in probabilistic distribution of particles. In both examples however, stochasticity is driven by the representation of space through boxes or triangular elements. When applied to the evolution of tracer concentration, the deterministic equation predicts that, at each time step, only a fraction of the tracer moves from one element to another. This approach is sufficient to mimic 
Markov stochastic processes.

In physical systems, each single state is a geographical area and the estimation of transition probabilities is usually based on physical simulations. Thompson et al. (2002) addressed the estimation of the transition matrix which would capture the essential mixing of particles in a macro-tidal system by simplifying the physical system and defining 15 states, that is, 15 geographical areas. They checked that the probability of a particle to stay in each state, move from one state to another or leave the system derived from the Markov Chain equation was close to the same probabilities derived from particle tracking with a 2D transport model. In our study, each element of the 2D computational grid was defined as one state and we averaged the exchange parameters over time in a way that made the estimation of a stationary transition matrix feasible. We checked that the trajectories of a tracer simulated by a Markov Chain model were consistent with the mixing patterns resulting from the initial transport equation. Some differences occurred but we estimated that they do not preclude the accuracy of our simplified transport scheme. It must be noted that the 3 systems we considered have very low tidal range (e.g. $1 \mathrm{~m}$ ) compared to Passamaquoddy bay studied by Thompson et al. (2002) (e.g. $8 \mathrm{~m}$ ). Water mixing is still tidally-driven but it is clear that the intensity, and therefore the spatial scales, is different by at least an order of magnitude. As outlined by Thompson et al. (2002), at some appropriate scale water mixing may be regarded as a stochastic process and this is why the use of Markov Chain is appropriate.

Freshwater flow is only included as a constant discharge which acts on the volume and momentum equations. The effect of water density is neglected and we only considered low discharge corresponding to summer conditions which is likely to have a minor influence on water circulation. We also neglected the effect of the wind in our application. A review of some recent works on the computation of residence time and connectivity shows that river flows and wind are taken into account in two different ways - e.g. scenarios or time series of real values (Table 2). Scenarios allow to repeat and compare calculations of residence time with forcing data which correspond to contrasted situations (Adams et al., 2012; Basterretxea et al., 2012; Braunschweig et al., 2003; Cucco and Umgiesser, 2006; De Brye et al., 2012; Plus et al., 2009; Ribbe et al., 2008; Shen and Wang, 2007; Tartinville et al., 1997; Thomas et al., 2012; Torréton et al., 2007; Wijeratne and Rydberg, 2007; Yuan et al., 2007). On the other hand, using real time series as forcing data makes it possible to assess residence time and connectivity when long time scales require to integrate the variability of forcing data or when the hydrodynamics is mostly driven by stochastic forcing (Abdelrhman, 2007; Deleersnijder et al., 2001; Delhez and Deleersnijder, 2002; Dumas et al., 2012; Ghezzo et al., 2015, 
Gourgue et al., 2007; Gustafsson and Bendtsen, 2007; Guydondet et al., 2013; Huang, 2007; Koutitonsky et al., 2004; Melaku Canu et al., 2012; Mudge et al., 2008; Orfila et al., 2005; Safak et al., 2015; Treml et al., 2008; Umgiesser et al., 2014). A more complete assessment of time scales would therefore require repeating our calculations for different scenarios of wind and freshwater inputs. Freshwater flows would have a marked seasonality and it is therefore feasible to consider scenarios of low/high freshwater input. The computation steps would be repeated for each scenario and the mapping of transfer times and rates, as well as the influences between farmed areas, would allow assessing the variability of the results as a function of river flows and give a range of values. Such an analysis would be consistent since the time scales lie within 1 or 2 months, which is still low compared to the annual seasonality of river flows. Now a true difficulty would arise if the variability of forcing must be taken into account. This would be the case when the energy spectrum of tidal oscillations is made of several periodic components. In this case, a solution might be to consider flows averaged over the highest tidal period, but there is no guarantee that the resulting mean flows would be accurate enough to make the Markov Chain calculation of transition probabilities close to the probabilities derived by simulation of particle tracking in a way similar to Thompson et al. (2002). Following these authors, a solution might require to increase spatial scales and build regions composed of set of elements that would account for the mixing at larger temporal scales. More problematic is the case where stochastic forcing (e.g. wind) makes the hydrodynamics less regular. One possible solution is the same as above - e.g. integrate particle tracking over longer time scales and adapt the spatial scale accordingly prior to the estimation of transition probabilities. Another solution might be found in recent developments of Markov set-chains (Samuels, 2001) which make possible to take into account the variability of transition probabilities.

\subsection{Comparison of systems}

Our 3 study sites are shallow estuaries influenced by tides with middle range amplitude (e.g. 1 $\mathrm{m})$. Water exchange between the bays and external waters is limited by narrow inlets. We found a clear difference between the time scales through the estimation of residence time (transfer time between every single element and the boundary), the average residence time of each system, and the map of transfer times between an element located in the vicinity of the inlet and all other elements. Richibucto estuary has the smallest time scales (e.g. average residence time equals 13 days), Malpeque bay the longest time scales (average residence time is 38 days) and Tracadie bay is intermediate (e.g. 23 days). This ranking is confirmed by the 
distribution of transfer times between all pairs of elements within each system (not shown). It is also confirmed by the estimation of renewal times based on the tidal prism method (Table 1). The explanation must be found in the morphological characteristics and bulk exchange rates (Table 1). The volume of Tracadie bay $\left(4410^{6} \mathrm{~m}^{3}\right)$ is comparable to Richibucto estuary $\left(58.410^{6} \mathrm{~m}^{3}\right)$ and they are both an order of magnitude lower than Malpeque bay $\left(63010^{6} \mathrm{~m}^{3}\right)$. The bulk exchange rate of Tracadie bay $\left(868 \mathrm{~m}^{3} \mathrm{~s}^{-1}\right)$ is more than twice lower than Richibucto $\left(2040 \mathrm{~m}^{3} \mathrm{~s}^{-1}\right)$ which explains why the mixing time scales of Tracadie are larger than Richibucto.

The differences in exchange rates and the morphological features explain the distribution of residual currents (Fig. 3) which show that Richibucto has more intense currents than the 2 other systems. Transfer times and rates between any pair of elements result from the preferential pathways of particles which integrate residual currents over space. Therefore high residual currents with a region of a bay generally make transfer times between 2 elements of that region lower compared to a region where the residual currents are weak. The patterns are however more complex in regions with gradients of current velocity, which explains why the maps of transfer rates and times (Fig. 4 and 5) do not always coincide with the maps of residual currents. While transfer times are obviously small in the vicinity of the inlets, some regions with high local exchanges (i.e. high residual currents) may have long transfer times see residence time in the narrow areas inside Richibucto for instance.

The distribution of transfer times and rates also relates to the morphological complexity to some extent. Complexity was measured as the ratio between the actual length of the coastline $(P)$ within each system, and the perimeter of an idealised system with the same area $(A)$ and a regular perimeter (e.g. circle). Morphological complexity therefore scales to the ratio $\frac{P}{\sqrt{A}}$ and the lowest value was found for Tracadie bay (complexity =9) as opposed to the two other systems which have very similar complexity (e.g. 21 for Malpeque bay, 22 for Richibucto estuary). We did not find any relation between complexity and residence time values, but the distribution of transfer times between all pairs of elements (not shown) exhibited higher variability for the systems with high complexity. This link can actually be explained by the higher transfer times found in narrow branches of the systems where water renewal is more difficult. In a comparison of residence times and connectivity calculated in 3 lagoons, Ghezzo et al. (2015) also identified the morphology as a factor explaining the differences between lagoons. However, the review of other recent studies clearly shows that mixing scales cannot be related to a single factor. In a study of 14 bays, Safak et al. (2015) did find that proximity 
to the inlet exerts a critical control on residence time but did not find any relationship between bay area, high tide volume and average depth and median residence times. However they found longer residence times in bays with a higher fraction of tidal area versus open-water area. It must be noted that the tidal range observed in their systems was almost twice as high as in our case. Abdelrhman (2005) compared residence times for a large number of embayments in a region where the maximum tidal amplitude is ca. $2 \mathrm{~m}$. He found a significant relationship between flushing time (similar to our residence time, though it has been calculated in a different way) and a combination of morphological variables - e.g. bay length, surface area. Most of his systems were small bays, with areas generally smaller than $5 \mathrm{~km}^{2}$ and residence time lower than 5 days. Abderlhman (2005) proposed to use his relationship to provide first-order estimates for bays in the same region, but it is clear that it would not apply for a wider range of systems. Therefore, the large amount of information brought by the computation of transfer times and rates can hardily be replaced by some general rules since mixing time scales clearly depend on local factors (e.g. physical forcing - wind, tide, river flows, bay geometry, spatial scales).

The use of common indicators of mixing scales allows comparing systems. Ghezzo et al. (2014) used a classification of lagoons into leaky, restricted and chocked categories on the basis of water renewal times. The same categories were considered by Umgiesser et al. (2014) as a way to compare 10 Mediterranean lagoons. Their classification was related to water renewal time (WRT), water flushing time (WFT), the fraction of the bay/lagoon volume renewed every day $(\mathrm{FVE}=1 / \mathrm{WFT})$ and the mixing efficiency $(\mathrm{ME}=\mathrm{WFT} / \mathrm{WRT})$. WRT reflects the real flushing and was estimated by Umgiesser et al. (2014) by simulating a tracer. In our case, it is approximated by the residence time (MCRT). WFT is based on the assumption that the bay/lagoon would be well mixed and is equal to $\mathrm{V} / \mathrm{Q}$, where $\mathrm{V}$ is the volume and Q the water flux flowing out of the system. WFT is usually greater than the WRT and the mixing efficiency therefore lies between 0 and 1 . Mixing efficiency close to 1 corresponds to well mixed systems. We computed the same indices (Table 1) for our 3 study sites. MCRT is comparable to the WRT of Venice, Taranto and Nador lagoons which all lie within 10 and 53 days and were affected to the 'restricted' category. We found very similar mixing efficiency for the 3 bays, with values close to 0.1 , which means that the bays were poorly mixed. Our values compare well to Venice and Ganzirri lagoons, where ME is equal to 0.15. Regarding FVE, we found a range of values lying between 0.28 and 0.61 , as opposed to the Mediterranean lagoons which, except for Venice $(\mathrm{FVE}=0.65)$ and Marano-Grado ( $\mathrm{FVE}=1.15)$, had values lower than 0.1. As far as these indicators are concerned, there is 
therefore some analogy between our bays and Venice lagoon and much less differences emerge from the comparison of our bays compared to the Mediterranean lagoons. Interestingly, dimensions of Venice lagoon is much comparable to Malpeque bay, and the dimensions of the Mediterranean lagoons cover a wide range of areas and volumes. Size is therefore not sufficient to explain the similarities of mixing scales between systems.

\subsection{Comparison with other approaches of residence time}

Most of the calculations of residence time are based on hydrodynamic models and the most popular applications are based either on Lagrangian or Eulerian approaches (Table 2). As mentioned by Ghezzo et al. (2015), the Eulerian transport scheme considers that the coordinates of the system remain fixed in space and the exchange of the fluid is computed in every fixed location of a grid where current velocity and tracer concentration are calculated. In the Lagrangian transport scheme, trajectories of a set of particles with different initial coordinates are simulated and statistical analysis of particle positions is performed to assess the main transport characteristics of the system. Our review of 35 recent works dealing with residence time indicates that 21 chose Eulerian and 10 preferred Lagrangian methods. Lagrangian methods allow taking into account stochastic processes (e.g. random fluctuations of velocity field), behaviour and life history of simulated particles. These features are of interest in the case of interactions between particles and environmental factors and development stage (Thomas et al., 2012, Basterretxea et al., 2012; Lett et al., 2008). Comparison of the pros/cons of these 2 methods is out of the scope of this paper, and interested readers are referred to Döös and Engqvist (2007) for instance. In our study, Markov Chain considers Eulerian scheme but it has already been noted that transition probabilities could be derived from Lagrangian simulations (Thompson et al., 2002). Our choice was only dictated by the simplicity of the computation of average flows and the derivation of transition matrix on this basis.

We applied Markov chain to compute average transfer times between any pair of elements used in the computation grid. A special case concerns the transfer times between an element inside the system and a boundary element. In this case, maps of transfer times display the average time needed for some tracer to leave the system. This is analogous to the residence time found in other studies, but this definition must be distinguished from the local residence time (LRT) used in other studies (Koutitonsky et al., 2004) even if we found similar patterns. When transfer times were averaged over space, we obtained an estimation of residence time, defined here as the average time needed for a particle to leave the system, equivalent to the 
classical definition found elsewhere (e.g. Safak et al., 2015).

Several studies that are reported in Table 2 combine residence time estimations and other quantities. The estimation of particle age is complementary to the concept of residence time. It usually requires the use of a partial differential equation for which details may be found in Delhez and Deleersnijder (2002), De Brye et al. (2012), Deleersnijder et al. (2001). We did not explore this concept further but, since Markov Chain deals with transition probabilities for any pair of element, an application to the age distribution of particles seems feasible. Another interesting concept found in a few studies is defined as connectivity. Definitions and a review of some applications are given in Table 2 (Ghezzo et al., 2015; Basterretxea et al., 2012; Thomas et al., 2012; Treml et al., 2008). Ghezzo et al. (2015) computed the accumulation of particles exchanged between $\mathrm{i}$ and $\mathrm{j}$ location, and built a square matrix with $\mathrm{i}$-rows and $\mathrm{j}$ columns expressing the connectivity of each $\mathrm{j}$-station with respect to itself and to the other stations. The result is very similar to the computation of transfer rates with Markov Chains, though we restricted the rates to the first passage of a tracer leaving element $j$ and reaching element i. Using connectivity analysis Ghezzo et al. (2015) made a global description of the preferential pathways within 3 lagoons and defined transition, retention and no connection regions in each system. Spatial interactions rely upon the idea that particles may be emitted in some place and be transported to another location - see the application of network analysis to sea lice dispersal by Adams et al. (2012). Interactions might also be related to the depletion of particles (e.g. phytoplankton) due to filtration by cultivated filter feeders, which would have a remote impact on distant animals because of the circulation pathways (Filgueira et al., in press). A third example is related to the recruitment of populations which larvae have a pelagic phase (Thomas et al., 2012; Basterretxea et al., 2012). In our study, we combined transfer rates and times to assess the main pathways of virtual particles released in farmed areas and the potential influence of farmed areas on other areas. The analysis is therefore qualitative, but it is very flexible and criteria can be easily changed to assess the sensitivity of the results to threshold values defined for screening the main pathways.

Confinement is another interesting concept that Ghezzo et al. (2014) proposed to relate to mixing scales. The confinement paradigm was introduced by Guélorget et al. (1994) to explain the spatial variation of species distribution inside lagoons. Ghezzo et al. (2014) suggested that residence time could be considered as a proxy of confinement but Melaku Canu et al. (2012) preferred to relate confinement to the time required for each element of the domain to accumulate a given amount of a conservative tracer that is displaced from the open sea into the lagoon or bay. Confinement is computed by simulating the increments of tracer 
concentration initially set to 0 in all elements and to a constant concentration at the boundary. Melaku Canu et al. (2012) applied this concept to Venice lagoon and mapped the rate of increase of concentration which was interpreted as a measure of confinement: the slower the accumulation and the higher the confinement. The calculation of the main pathways, transfer rates and times that we performed with Markov Chains concept provides a complementary indication of confinement. Figure 5 shows the transfer rates and times between sites situated at the entrance of the bays. Areas with high transfer times and low transfer rates would likely coincide with confined areas. In addition confinement could also be defined as sectors of the bay that are poorly connected to other sectors and therefore be characterized on the basis of connectivity indicators. In our study, the map of the locations which have a low connectivity with existing aquaculture areas illustrate the confinement of the aquaculture area. In this context, confinement would not be limited to the connection between the entrance of the bay and the locations within the bay.

\section{Conclusion}

To our knowledge, this is the first time that Markov Chain analysis has been applied to assess residence time in physical systems represented with 2D models. Our study explains how to apply Markov chain computation to quantify transfer times and rates of matter between any location, using the outputs of $2 \mathrm{D}$ models to assess the transition matrix between the elements of the computation grid. Compared to tracer simulations, the main advantage of Markov Chain analysis is that it provides additional information on the mixing scales over time or over space. It makes possible to estimate transfer rates and times at once in a very quick and efficient way, without the need to perform long term simulation of particle trajectories or tracer concentration. Another output, not shown here but extensively explained in the seminal paper by Leguerrier et al. (2006), is the estimation of the number of times a particle originating from one location would pass at a another location. This can be of great interest in estimating how much time a particle would stay in a region with applications to ecological issues - e.g. species recruitment, risks related to pathogen transmission. As an example of the added value of Markov Chain analysis, we show the assessment of the connectivity between aquaculture sites and other sectors of the bays. Such estimation has proved useful and complementary to other indicators used to assess the development of aquaculture - see Filgueira et al. (in press).

We also review the assumptions made in the use of Markov Chain and the limitations of the method. First, we discussed the averaging of the exchange parameters over time in a way that 
makes the estimation of a stationary transition matrix feasible. The averaging includes neap/spring tidal cycles and it is true that some information is probably lost during this process. However we compared some simulations based on transition probabilities with simulations run with the RMA model. We noted that water mixing was tidally-driven and we could neglect the effect of the wind in our case. Second, deviation from stationarity can be addressed in different ways, depending on the source of the non-stationarity, in reference to Thompson et al. (2002) who stated that, at some appropriate scale, water mixing may be regarded as a stochastic process and the use of Markov Chain is therefore relevant. The first way to alleviate non-stationarity comes from fact that the scale depends on the drivers and intensity of mixing. Thompson et al. (2002) aggregated the results at a spatial scale larger than the scale used to simulate the transport of tracers by discretizing the bay into 15 boxes. They also upscaled the processes time scale up to days, and therefore integrated shorter time scales into their matrix of transition probabilities. A second way would consist in repeating the calculations for different scenarios of tide, wind and freshwater inputs. This is relevant when seasonal variability is concerned, which is often the case for freshwater inputs for instance. The third solution might be found in recent developments of Markov set-chains (Samuels, 2001) which make possible to take into account the variability of transition probabilities, but these developments remain to be implemented.

As a conclusion, we suggest that the Markov Chain analysis is very suitable for tidally-driven systems with short term mixing scales - e.g. 1 month. The use of residence time and related measures is proposed as a tool for management purpose in aquaculture (Adams et al., 2012; Thomas et al., 2012), design and assessment of marine protected areas (Basterretxea et al. 2012), assessment of ecosystem health (Abdelrhman, 2007). Markov Chain analysis could then be applied to a variety of fields.

\section{Acknowledgement}

The work presented in this paper was partly funded by the Department of Fisheries and Oceans of Canada (Program for Aquaculture Regulatory Research, PARR project 2011-Z-22).

\section{Literature cited}

Abdelrhman, M. A., 2005. Simplified modeling of flushing and residence times in 42 embayments in New England, USA, with special attention to Greenwich Bay, Rhode Island. Estuar. Coast. Shelf Sci. 62 (1-2), 339-351. 
Abdelrhman, M. A., 2007. Embayment characteristic time and biology via tidal prism model. Estuar. Coast. Shelf Sci. 74 (4), 742-755.

Adams, T., Black, K., MacIntyre, C., MacIntyre, I., Dean, R., 2012. Connectivity modelling and network analysis of sea lice infection in Loch Fyne, west coast of Scotland. Aquacult. Environ. Interact. 3 (1), 51-63.

Bailey, N. T. J., 1964. The elements of stochastic processes with applications to the natural sciences. New York: J. Wiley, 249 pp.

Basterretxea, G., Jordi, A., Catalán, I. A., Sabatés, A., 2012. Model-based assessment of local-scale fish larval connectivity in a network of marine protected areas. Fish. Oceanogr. 21 (4), 291-306.

Benabdellah, B., Albrecht, K.F., Pomaz, V.L., Denisenko, E.A., Logofet, D.O., 2003. Markov chain model for forest successions in the Erzgebirge, Germany. Ecol. Model. 159, 103-302.

Bolin, B., Rodhe, H., 1973. A note on the concepts of age distribution and transit time in natural reservoirs. Tellus 25, 58-62.

Braunschweig, F., Martins, F., Chambel, P., Neves, R., 2003. A methodology to estimate renewal time scales in estuaries: the Tagus Estuary case. Ocean Dyn. 53 (3), 137-145.

Brooks, D. A., Baca, M. W., Lo, Y., 1999. Tidal Circulation and Residence Time in a Macrotidal Estuary : Cobscook Bay, Maine. Estuar. Coast. Shelf Sci. 49, 647-665.

Cloern, J.E., 1982. Does the benthos control phytoplankton biomass in South San Francisco Bay? Mar. Ecol. Progr. Ser. 9, 191-202.

Cucco, A., Umgiesser, G., 2006. Modeling the Venice Lagoon residence time. Ecol. Model. $193(1-2), 34-51$.

Dame, R.F., Prins, T.C, 1998. Bivalve carrying capacity in coastal ecosystems. Aquat. Ecol. 31, 409-421.

De Brye, B., de Brauwere, A., Gourgue, O., Delhez, E. J. M., Deleersnijder, E., 2012. Water renewal timescales in the Scheldt Estuary. J. Mar. Syst. 94, 74-86.

Deleersnijder, E., Campin, J., Delhez, E. J. M., 2001. The concept of age in marine modelling I . Theory and preliminary model results. J. Mar. Syst. 28, 229-267.

Delhez, E.J.M., Deleersnijder, E., 2002. The concept of age in marine modelling: II. Concentration distribution function in the English Channel and the North Sea. J. Mar. Syst. 31, 279-297. 
Döös, K., Engqvist, A., 2007. Assessment of water exchange between a discharge region and the open sea - A comparison of different methodological concepts. Estuar. Coast. Shelf Sci. 74 (4), 709-721.

Dumas, F., Le Gendre, R. Le, Thomas, Y., Andréfouët, S., 2012. Tidal flushing and wind driven circulation of Ahe atoll lagoon (Tuamotu Archipelago, French Polynesia) from in situ observations and numerical modelling. Mar. Pollut. Bull. 65 (10-12), 425-440.

Filgueira, R., Guyondet, T., Bacher, C., Comeau, L.A., in press. Carrying Capacity for Mussel Aquaculture in Malpeque Bay, Prince Edward Island. Mar. Pollut. Bull.

Filgueira, R., Guyondet, T., Comeau, L. A., Grant, J., 2014. A fully-spatial ecosystem-DEB model of oyster (Crassostrea virginica) carrying capacity in the Richibucto Estuary, Eastern Canada. J. Mar. Syst. 136, 42-54.

Filgueira, R., Guyondet, T., Comeau, L. A., Grant, J., 2013. Storm-induced changes in coastal geomorphology control estuarine secondary productivity. Earth's Future, doi:10.1002/2013EF000145

Filgueira, R., Grant, J., Bacher, C., Carreau, M., 2012. A physical biochemical coupling scheme for modeling marine coastal ecosystems. Ecol. Inform. 7, 71-80.

Ghezzo, M., De Pascalis, F., Umgiesser, G., Zemlys, P., Sigovini, M., Marcos, C., PérezRuzafa, A., 2015. Connectivity in Three European Coastal Lagoons. Estuar. Coasts 38, 1764-1781.

Gourgue, O., Deleersnijder, E., White, L., 2007. Toward a generic method for studying water renewal, with application to the epilimnion of Lake Tanganyika. Estuar. Coast. Shelf Sci.74 (4), 628-640.

Guélorget, O., Perthuisot, J.P., Lamy, N., Lefebvre, A., 1994. Structure et organisation de l'étang de Thau d'après la faune benthique. Oceanologica Acta 1, 105-114.

Gustafsson, K. E., Bendtsen, J., 2007. Elucidating the dynamics and mixing agents of a shallow fjord through age tracer modelling. Estuar. Coast. Shelf Sci. 74 (4), 641-654.

Guyondet, T., Koutitonsky, V.G., Roy, S., 2005. Effects of water renewal estimates on the oyster aquaculture potential of an inshore area. J. Mar. Syst. 58, 35-51.

Guyondet, T., Sonier, R., Comeau, L., 2013. Spatially explicit seston depletion index to optimize shellfish culture. Aquacult. Environ. Interact. 4 (2), 175-186.

Hill, M. F., Witman, J. D., Caswell, H., 2004. Markov Chain Analysis of Succession in a Rocky Subtidal Community. Am. Nat. 164 (2), 46-61.

Hily, C.,, 1991. Is the activity of benthic suspension feeders a factor controlling water quality in the Bay of Brest? Mar. Ecol. Progr. Ser. 69, 179-188. 
Huang, W., 2007. Hydrodynamic modeling of flushing time in a small estuary of North Bay, Florida, USA. Estuar. Coast. Shelf Sci. 74 (4), 722-731.

Koutitonsky, V. G. K., Guyondet, T. G., St-Hilaire, A., Courtenay, S. C., Bohgen, A., 2004. Water Renewal Estimates for Aquaculture Developments in the Richibucto Estuary, Canada. Estuaries 27 (5), 839-850.

Leguerrier, D., Bacher, C., Benoit, E., Niquil, N., 2006. A probabilistic approach of flowbalanced network based on Markov chains. Ecol. Model. 193 (3-4), 295-314.

Lett, C., Verley, P., Mullon, C., Parada, C., Brochier, T., Penven, P., Blanke, B., 2008. A Lagrangian tool for modelling ichthyoplankton dynamics. Environ. Model. Softw. 23 (9), 1210-1214.

Logofet, D.O, Lesnaya, E.V., 2000. The mathematics of Markov models: what can Markov chains can realy predict in forest successions? Ecol. Model. 126, 285-298.

Melaku Canu, D., Umgiesser, G., Solidoro, C., Cucco, A., Ferrarin, C., 2012. Assessing confinement in coastal lagoons. Mar. Pollut. Bull. 64, 2391-2398.

Miller, R.L., McPherson, B.F., 1991. Estimating estuarine flushing and residence times in Charlotte Harbor, Florida, via salt balance and a box model. Limnol. Oceanogr. 36, 602-612.

Moilanen, A., 2004. SPOMSIM: software for stochastic patch occupancy models of metapopulation dynamics. Ecol. Model. 179, 533-550.

Monsen, N.E., Cloern, J.E., Lucas, L.V., 2002. A comment on the use of flushing time, residence time and age as transport time scales. Limnol. Oceanogr. 47 (5), 1545-1553.

Mudge, S. M., Icely, J. D., Newton, A., 2008. Residence times in a hypersaline lagoon: Using salinity as a tracer. Estuar. Coast. Shelf Sci. 77 (2), 278-284.

Officer, C.B., Smayda, T.J., Mann, R., 1982. Benthic filter feeding: a natural eutrophication control. Mar. Ecol. Progr. Ser. 9, 203-210.

Orfila, A., Jordi, A., Basterretxea, G., Vizoso, G., Marbà, N., Duarte, C. M., Werner, F.J., Tintoré, J., 2005. Residence time and Posidonia oceanica in Cabrera Archipelago National Park, Spain. Cont. Shelf Res. 25 (11), 1339-1352.

Patten, B.C., Higashi, M., 1995. First passage flow in ecological networks: measurement by input-output flow analysis. Ecol. Model. 79, 67-74.

Plus, M., Dumas, F., Stanisière, J. Y., Maurer, D., 2009. Hydrodynamic characterization of the Arcachon Bay, using model-derived descriptors. Cont. Shelf Res. 29 (8), 10081013. 
Ribbe, J., Wolff, J.-O., Staneva, J., Gräwe, U., 2008. Assessing water renewal time scales for marine environments from three-dimensional modelling: A case study for Hervey Bay, Australia. Environ. Model. Softw. 23 (10-11), 1217-1228.

Safak, I., Wiberg, P. L., Richardson, D. L., Kurum, M. O., 2015. Controls on residence time and exchange in a system of shallow coastal bays. Cont. Shelf Res. 97, 7-20.

Samuels, C. L., 2001. Markov set-chains as models of plant succession. PhD diss., University of Tennessee, http://trace.tennessee.edu/utk_graddiss/2075

Shen, J., Wang, H. V., 2007. Determining the age of water and long-term transport timescale of the Chesapeake Bay. Estuar. Coast. Shelf Sci. 74 (4), 585-598.

Smagorinsky, J., 1963. General circulation experiment with the primitive equations. Monthly Weather Review 91, 99-164.

Takeoka, H., 1984. Fundamental concepts of exchange and transport time scales in a coastal sea. Cont. Shelf Res. 3, 311-326.

Tartinville, B., Deleersnijder, E., Rancher, J., 1997. The water residence time in the Mururoa atoll lagoon: sensitivity analysis of a three-dimensional model. Coral Reefs 16 (3), 193-203.

Thomas, Y., Gendre, R. Le, Garen, P., Dumas, F., Andréfouët, S., 2012. Bivalve larvae transport and connectivity within the Ahe atoll lagoon (Tuamotu Archipelago), with application to pearl oyster aquaculture management. Mar. Pollut. Bull. 65 (10-12), $441-452$.

Thompson, K.R., Dowd, M., Shen, Y., Greenberg, D.A., 2002. Probabilistic characterization of tidal mixing in a coastal embayment: a Markov Chain approach. Cont. Shelf Res. $22,1603-1614$.

Torréton, J.-P., Rochelle-Newall, E., Jouon, A., Faure, V., Jacquet, S., Douillet, P., 2007. Correspondence between the distribution of hydrodynamic time parameters and the distribution of biological and chemical variables in a semi-enclosed coral reef lagoon. Estuar. Coast. Shelf Sci. 74 (4), 766-776.

Treml, E. a., Halpin, P. N., Urban, D. L., Pratson, L. F., 2008. Modeling population connectivity by ocean currents, a graph-theoretic approach for marine conservation. Landsc. Ecol. 23 (S1), 19-36.

Tucker, B.C., Anand, M., 2004. The Application of Markov Models in Recovery and Restoration. Int. J. Ecol. Environ. Sci. 30, 131-140. 
Umgiesser, G., Ferrarin, C., Cucco, A., De Pascalis, F., Bellafiore D., Ghezzo, M., Bajo, M., 2014. Comparative hydrodynamics of 10 Mediterranean lagoons by means of numerical modelling. J. Geophys. Res. Oceans 119, 2212-2226.

Wijeratne, E. M. S., Rydberg, L., 2007. Modelling and observations of tidal wave propagation, circulation and residence times in Puttalam Lagoon, Sri Lanka. Estuar. Coast. Shelf Sci. 74 (4), 697-708.

Yuan, D., Lin, B., Falconer, R., 2007. A modelling study of residence time in a macro-tidal estuary. Estuar. Coast. Shelf Sci. 71 (3-4), 401-411.

Zimmerman, J.T.F., 1976. Mixing and flushing of tidal embayments in the western Dutch Wadden Sea. Part I: distribution of salinity and calculation of mixing time scales. Neth. J. Sea Res. 10, 149-161. 


\begin{tabular}{|c|c|c|c|c|}
\hline & & $\begin{array}{c}\text { Richibucto } \\
\text { Estuary }\end{array}$ & $\begin{array}{c}\text { Tracadie } \\
\text { Bay }\end{array}$ & $\begin{array}{c}\text { Malpeque } \\
\text { Bay }\end{array}$ \\
\hline Surface area $(\mathrm{A})$ & $\mathrm{km}^{2}$ & 33,2 & 19,4 & 223,6 \\
\hline $\begin{array}{l}\text { Volume at mean sea level } \\
\text { (V) }\end{array}$ & $10^{6} \mathrm{~m}^{3}$ & 58,4 & 44,0 & 629,5 \\
\hline Coastline $(\mathrm{P})$ & $\mathrm{km}$ & 125,4 & 2 & 308,6 \\
\hline Complexity $\left(\mathrm{P} / \mathrm{A}^{1 / 2}\right)$ & - & 22 & 9 & 21 \\
\hline Tidal range & $\mathrm{m}$ & $0.3-1.3$ & $0.3-1.0$ & $0.3-1.1$ \\
\hline Exchange & $m^{3} s^{-1}$ & 2040.4 & 867.9 & 10048.6 \\
\hline Mean outflow (Q) & $\mathrm{m}^{3} \mathrm{~s}$ & & 156.6 & 2021.6 \\
\hline $\begin{array}{l}\text { Spatially averaged RMS } \\
\text { current }\end{array}$ & & 0.08 & 0.03 & 0.06 \\
\hline Renewal time (tidol nrism) neap & & 6.6 & 8.4 & 10.3 \\
\hline & & 1.9 & 2.9 & 3.2 \\
\hline $\begin{array}{l}\text { Residence time (Markov } \\
\text { Chain, MCRT) }\end{array}$ & $\mathrm{d}$ & 13.1 & 23.4 & 38.1 \\
\hline $\begin{array}{l}\text { Water Flushing Time }(\text { WFT } \\
=\mathrm{V} / \mathrm{Q})\end{array}$ & d & 1.6 & 3.3 & 3.6 \\
\hline $\begin{array}{l}\text { Fraction of volume renewed } \\
\text { daily }(\mathrm{FVE}=1 / \mathrm{WFT})\end{array}$ & & 0.61 & 0.31 & 0.28 \\
\hline $\begin{array}{l}\text { Mixing efficiency }(\mathrm{ME}= \\
\text { WFT/RTMC) }\end{array}$ & & 0.12 & 0.14 & 0.09 \\
\hline Typical grid cell size & $\mathrm{m}$ & $60-350$ & $60-200$ & $90-300$ \\
\hline Number of grid cells & & 3581 & 2188 & 5171 \\
\hline
\end{tabular}

Table 1. Main characteristics of the 3 study sites 


\begin{tabular}{|c|c|c|c|c|}
\hline Objective & $\begin{array}{l}\text { Modelling } \\
\text { method }\end{array}$ & System & $\begin{array}{l}\text { Driving } \\
\text { forces }\end{array}$ & Source \\
\hline $\begin{array}{l}\text { To simulate tidal flushing, distributions of tidal and subtidal } \\
\text { current speeds, and distributions of conservative constituents } \\
\text { for } 42 \text { embayments. } \\
\text { To relate the flushing time and the physical parameters of the } \\
\text { embayments. } \\
\text { To compare model results for a subset of the systems with } \\
\text { published results to show that the procedure reproduces the } \\
\text { flushing behaviour of the systems reasonably well. } \\
\text { Spatial distribution of the time scales of local transport, which } \\
\text { can be more relevant to local ecological and biological } \\
\text { components within an embayment }\end{array}$ & $\begin{array}{l}2 \mathrm{D} \\
\text { hydrodynamics } \\
\text { Eulerian }\end{array}$ & $\begin{array}{l}42 \text { embayments in } \\
\text { southern New } \\
\text { England (USA) }\end{array}$ & Tide & $\begin{array}{l}\text { Abdelrhman } \\
(2005)\end{array}$ \\
\hline $\begin{array}{l}\text { To use simple model to assess the relationship between } \\
\text { transport time scales and biology. } \\
\text { To identify the effect of constituent loading patterns and the } \\
\text { relevant transport times on the exposure of a biological } \\
\text { component in an embayment (or suite of embayments). }\end{array}$ & Tidal prism & $\begin{array}{|lr|}18 & \text { embayments } \\
\text { located } & \text { within } \\
\text { Narragansett } & \text { Bay } \\
(\text { USA) } & \\
\end{array}$ & $\begin{array}{l}\text { Tide } \\
\text { River flow } \\
\text { (real values) }\end{array}$ & $\begin{array}{l}\text { Abdelrhman } \\
(2007)\end{array}$ \\
\hline $\begin{array}{l}\text { To understand the larval dispersal of sea lice among a network } \\
\text { of aquaculture sites within a system that is effectively closed to } \\
\text { infection by larvae from farms elsewhere. } \\
\text { To combine of hydrodynamic and biological models, and } \\
\text { analysis of outputs using metrics from graph theory. } \\
\text { To identify key sites for management, and understanding of the } \\
\text { main dispersal pathways for farm siting, improving timing and } \\
\text { reducing intensity of treatments, as well as reducing } \\
\text { transmission between farmed and wild fish. }\end{array}$ & $\begin{array}{l}\text { 2D } \\
\text { Hydrodynamic } \\
\text { modelling } \\
\text { Particle tracking } \\
\text { (Lagrangian) } \\
\text { Metapopulation } \\
\text { Network analysis }\end{array}$ & $\begin{array}{ll}\text { Loch } & \text { Fyne } \\
\text { (Scotland) } & \end{array}$ & $\begin{array}{l}\text { Wind } \\
\text { (scenarios) } \\
\text { Tide }\end{array}$ & $\begin{array}{l}\text { Adams et al. } \\
(2012)\end{array}$ \\
\hline $\begin{array}{l}\text { To analyze, at scales of kilometers, the connectivity patterns of } \\
\text { the inner-shelf larval fish species and how they are affected by } \\
\text { wind-driven circulation in order to understand the drivers of } \\
\text { coastal recruitment and the level of exchange in networked } \\
\text { MPAs. }\end{array}$ & $\begin{array}{l}\text { Hydrodynamic } \\
\text { model } \\
\text { Particle tracking } \\
\text { (Lagrangian) } \\
\text { Network analysis } \\
\text { (connectivity) }\end{array}$ & $\begin{array}{l}\text { Southern coast of } \\
\text { Mallorca (Spain) }\end{array}$ & $\begin{array}{l}\text { Tide } \\
\text { Wind } \\
\text { (scenarios) }\end{array}$ & $\begin{array}{l}\text { Basterretxea et } \\
\text { al. (2012) }\end{array}$ \\
\hline $\begin{array}{l}\text { To quantify residence times and integrated water fraction to } \\
\text { understand the history of renewal in each region. } \\
\text { To compare renewal parameters with ecological results to } \\
\text { assess the importance of transport in the biological processes }\end{array}$ & $\begin{array}{l}2 \mathrm{D} \\
\text { hydrodynamic } \\
\text { model } \\
\text { Lagrangian } \\
\text { Dependency } \\
\text { matrix }\end{array}$ & \begin{tabular}{|ll} 
Tagus & estuary \\
(Portugal) &
\end{tabular} & $\begin{array}{l}\text { Tide } \\
\text { River flow } \\
\text { (scenarios) } \\
\text { Wind } \\
\text { (scenarios) }\end{array}$ & $\begin{array}{l}\text { Braunschweig et } \\
\text { al. (2003) }\end{array}$ \\
\hline $\begin{array}{l}\text { To improve understanding of the tidal circulation, dispersion } \\
\text { and flushing times. }\end{array}$ & $\begin{array}{l}\text { 3D model } \\
\text { Lagrangian }\end{array}$ & \begin{tabular}{|l|l|}
$\begin{array}{l}\text { Cobscook } \\
\text { (USA) }\end{array}$ & Bay \\
\end{tabular} & Tide & $\begin{array}{l}\begin{array}{l}\text { Brooks } \\
(1999)\end{array} \\
\end{array}$ \\
\hline $\begin{array}{l}\text { To compute the residence time, compare various forcing on the } \\
\text { renewal capacity of the basin and quantify the influence of the } \\
\text { return flow on residence times. }\end{array}$ & $\begin{array}{l}\text { 2D model } \\
\text { Eulerian }\end{array}$ & $\begin{array}{ll}\text { Venice } & \text { lagoon } \\
\text { (Italy) } & \end{array}$ & $\begin{array}{l}\text { Tide } \\
\text { Wind } \\
\text { (scenarios) }\end{array}$ & $\begin{array}{l}\text { Cucco and } \\
\text { Umgiesser } \\
(2006)\end{array}$ \\
\hline $\begin{array}{l}\text { To compute the residence time, age of particles and compare } \\
\text { the influence of discharge scenarios }\end{array}$ & $\begin{array}{l}\text { Eulerian } \\
\text { Adjoint approach }\end{array}$ & $\begin{array}{l}\text { Scheldt estuary } \\
\text { (Netherlands) }\end{array}$ & $\begin{array}{l}\text { Tide, } \\
\text { River flow } \\
\text { (scenarios) }\end{array}$ & $\begin{array}{l}\text { De Brye et al. } \\
(2012)\end{array}$ \\
\hline $\begin{array}{l}\text { To establish a general theory of age } \\
\text { To investigate the impact of mixing on the age, with a } \\
\text { particular focus on the differences between the age of the } \\
\text { water, the age of a passive tracer, the age of a radioactive } \\
\text { tracer, as well as a suitably-defined radio-age, i.e. a fluid parcel } \\
\text { age estimated from the concentration of a passive and a } \\
\text { radioactive constituent, assuming that mixing is negligible. } \\
\text { To assess the timescales of the long-term transport through the } \\
\text { English Channel and the southern North Sea by modelling the } \\
\text { age of tracers released by the La Hague nuclear fuel } \\
\text { reprocessing plant. } \\
\text { To compute the ages at the scale of the World Ocean }\end{array}$ & $\begin{array}{l}\text { 2D model } \\
\text { Eulerian } \\
\text { Age equation }\end{array}$ & $\begin{array}{l}\text { English Channel } \\
\text { (France, England), } \\
\text { World Ocean }\end{array}$ & $\begin{array}{l}\text { Tide } \\
\text { Wind } \quad \text { (real } \\
\text { values) }\end{array}$ & $\begin{array}{l}\text { Deleersnijder et } \\
\text { al. (2001) }\end{array}$ \\
\hline $\begin{array}{l}\text { To show that mixing raises the problem of the significance of } \\
\text { the mean age as a characterization of the full age distribution } \\
\text { and to show how the general theory of age can be used to } \\
\text { tackle this issue. }\end{array}$ & $\begin{array}{l}2 \mathrm{D} \\
\text { hydrodynamic } \\
\text { model } \\
\text { Eulerian } \\
\text { Concentration } \\
\text { distribution } \\
\text { function }\end{array}$ & $\begin{array}{l}\text { Theoretical English } \\
\text { Channel (France, } \\
\text { England) }\end{array}$ & $\begin{array}{l}\text { Tide } \\
\text { Wind } \quad \text { (real } \\
\text { values) }\end{array}$ & $\begin{array}{l}\text { Delhez and } \\
\text { Deleersnijder } \\
(2002)\end{array}$ \\
\hline To compare passive tracers and Lagrangian trajectories & $\begin{array}{l}3 \mathrm{D} \\
\text { hydrodynamic } \\
\text { model } \\
\text { Eulerian } \\
\text { Lagrangian }\end{array}$ & Baltic sea (Sweden) & Tide & $\begin{array}{l}\text { Döös and } \\
\text { Engqvist (2007) }\end{array}$ \\
\hline
\end{tabular}




\begin{tabular}{|c|c|c|c|c|}
\hline $\begin{array}{l}\text { To characterize the exchanges between the lagoon and the } \\
\text { ocean and the main regimes of lagoonal water circulation } \\
\text { related to waves, wind and tidal conditions } \\
\text { To characterize the lagoon circulation, map the lagoon e- } \\
\text { flushing time and compare the hydrodynamic functioning with } \\
\text { other lagoons }\end{array}$ & $\begin{array}{l}\text { 3D } \\
\text { hydrodynamic } \\
\text { model } \\
\text { Eulerian }\end{array}$ & \begin{tabular}{|ll} 
Ahe & lagoon \\
(France) &
\end{tabular} & $\begin{array}{ll}\text { Waves } & \\
\text { Tides } & \\
\text { Winds } \quad \text { (real } \\
\text { values) }\end{array}$ & \begin{tabular}{|lll} 
Dumas \\
$(2012)$
\end{tabular} et al. \\
\hline $\begin{array}{l}\text { To develop a method to calculate the connectivity in different } \\
\text { stations inside and outside the lagoon under different } \\
\text { environmental conditions. }\end{array}$ & $\begin{array}{l}\text { 2D model } \\
\text { Lagrangian } \\
\text { Connectivity }\end{array}$ & $\begin{array}{|lr|}3 & \text { European } \\
\text { lagoons: } & \text { Curonian } \\
\text { lagoon } & \text { (Lithuania), } \\
\text { Venice } & \text { lagoon } \\
\text { (Italy), Mar } & \text { Menor } \\
\text { (Spain) } & \\
\end{array}$ & $\begin{array}{l}\text { Tide } \\
\text { Wind } \quad \text { (real } \\
\text { values) }\end{array}$ & $\begin{array}{l}\text { Ghezzo et al. } \\
(2015)\end{array}$ \\
\hline $\begin{array}{l}\text { To present a method for studying water renewal that is based } \\
\text { on the idea that the water can be viewed as a mixture of } \\
\text { different water types depending on their origin. } \\
\text { To quantify the rate at which water is renewed by estimating } \\
\text { the residence time of the initial water and the age of the } \\
\text { renewing water }\end{array}$ & $\begin{array}{l}\text { D } \\
\text { model } \\
\text { Eulerian } \\
\text { Age equation }\end{array}$ & $\begin{array}{l}\text { Tanganyka lake } \\
\text { (Democratic } \\
\text { Republic of Congo, } \\
\text { Burundi, Tanzania, } \\
\text { Zambia) }\end{array}$ & $\begin{array}{l}\text { Water } \\
\text { exchange } \\
\text { Precipitation } \\
\text { River flow } \\
\text { Evaporation } \\
\text { (real values) }\end{array}$ & $\begin{array}{l}\text { Gourgue et al. } \\
(2007)\end{array}$ \\
\hline $\begin{array}{l}\text { To analyse the general dynamics in relation to the major } \\
\text { mixing agents in response to external forcing (e.g. tides and } \\
\text { winds). By analysing the vertical distribution of age tracers } \\
\text { released at bottom or surface, the vertical mixing in the fjord in } \\
\text { relation to external forcing was assessed. }\end{array}$ & $\begin{array}{l}\text { 3D model } \\
\text { Eulerian } \\
\text { Age equati }\end{array}$ & \begin{tabular}{|ll}
$\begin{array}{l}\text { Horsens } \\
(\text { Denmark) }\end{array}$ & Fjord \\
\end{tabular} & $\begin{array}{l}\text { Wind } \quad \text { (real } \\
\text { values) } \\
\text { Tide }\end{array}$ & $\begin{array}{l}\text { Gustafsson and } \\
\text { Bendtsen (2007) }\end{array}$ \\
\hline $\begin{array}{l}\text { To estimate seston availability for filter-feeders by simulating } \\
\text { the transport, production and consumption of seston and } \\
\text { bivalve biomass filtration and test more specifically effect of a } \\
\text { breach in the coastline on hydrodynamics and seston } \\
\text { availability. }\end{array}$ & $\begin{array}{l}2 \mathrm{D} \text { mod } \\
\text { Euleriar }\end{array}$ & $\begin{array}{l}\text { Richibucto estuary } \\
\text { (Canada) }\end{array}$ & $\begin{array}{l}\text { Wind } \\
\text { Tide } \\
\text { River flow } \\
\text { (real values) }\end{array}$ & $\begin{array}{l}\text { Guyondet et al. } \\
(2013)\end{array}$ \\
\hline To determine the freshwater fraction and flushing time & $\begin{array}{l}\text { 3D model } \\
\text { Eulerian } \\
\text { (salinity) }\end{array}$ & $\begin{array}{l}\text { North Bay (Florida, } \\
\text { USA) }\end{array}$ & $\begin{array}{l}\text { Tide } \\
\text { River flow } \\
\text { Wind (real } \\
\text { values) }\end{array}$ & Huang (2007) \\
\hline $\begin{array}{l}\text { To describe the hydrodynamic functioning and to estimate the } \\
\text { spatial distribution of the local residence time and its integral } \\
\text { residence time. }\end{array}$ & $\begin{array}{l}\text { 2D model } \\
\text { Eulerian }\end{array}$ & $\begin{array}{l}\text { Richibucto } \\
\text { (Canada) }\end{array}$ & $\begin{array}{l}\text { Tide } \\
\text { River flow } \\
\text { (scenarios) } \\
\text { Wind (real } \\
\text { values) }\end{array}$ & $\begin{array}{l}\text { Koutitonsky et } \\
\text { al. (2004) }\end{array}$ \\
\hline $\begin{array}{l}\text { To demonstrate the use of Markov Chain for the calculation of } \\
\text { preferential pathways }\end{array}$ & $\begin{array}{l}\text { Box model } \\
\text { Markov Chain }\end{array}$ & $\begin{array}{l}\text { Passamaquody bay } \\
\text { (Canada) }\end{array}$ & Tide & $\begin{array}{l}\text { Leguerrier et al. } \\
(2006)\end{array}$ \\
\hline $\begin{array}{l}\text { To propose a method to define confinement based on a marine } \\
\text { tracer accumulation rate as computed by a transport model. } \\
\text { To derive general recommendations for the assessment of } \\
\text { confinement by exploring the influence of the use of actual } \\
\text { high frequency forcing rather than climatological forcing and } \\
\text { the need to expand the computational domain up to and } \\
\text { including both the lagoon and its adjoining sea. }\end{array}$ & $\begin{array}{l}\text { 2D model } \\
\text { Eulerian }\end{array}$ & Venice lagoon & $\begin{array}{l}\text { Wind } \\
\text { Tide } \\
\text { River flow } \\
\text { (real value) }\end{array}$ & $\begin{array}{l}\text { Melaku Canu et } \\
\text { al. (2012) }\end{array}$ \\
\hline $\begin{array}{l}\text { To compare three transport time scales (flushing time, } \\
\text { residence time, age) commonly used to measure the retention } \\
\text { of water or scalar quantities transported with water. } \\
\text { To identify the underlying assumptions associated with each } \\
\text { time scale. } \\
\text { To describe procedures for computing these time scales in } \\
\text { idealized cases. } \\
\text { To identify pitfalls when real-world systems deviate from these } \\
\text { idealizations. }\end{array}$ & $\begin{array}{l}\text { 3D model } \\
\text { Lagrangian }\end{array}$ & \begin{tabular}{|l}
$\begin{array}{l}\text { Mildred } \\
\text { (USA) }\end{array}$ \\
\end{tabular} & $\begin{array}{l}\text { Tide } \\
\text { River flow }\end{array}$ & $\begin{array}{l}\text { Monsen et al. } \\
(2002)\end{array}$ \\
\hline $\begin{array}{l}\text { To investigate the hypothesis that a significant amount of the } \\
\text { water in the lagoon is not exchanged with the north Atlantic } \\
\text { and, while flushing is good in the outer parts of the lagoon, the } \\
\text { inner reaches are poorly flushed. }\end{array}$ & Box model & $\begin{array}{ll}\text { Ria } & \text { Formosa } \\
\text { (Portugal) } & \end{array}$ & $\begin{array}{l}\text { River flow } \\
\text { (real values) } \\
\text { Tide }\end{array}$ & \begin{tabular}{|l} 
Mudge et al. \\
$(2008)$
\end{tabular} \\
\hline $\begin{array}{l}\text { To estimate both the flushing and residence times in the } \\
\text { context of the health of seagrass meadows. }\end{array}$ & $\begin{array}{l}\text { 2D model } \\
\text { Lagrangian }\end{array}$ & $\begin{array}{l}\text { Cabrera National } \\
\text { Park (Spain) }\end{array}$ & $\begin{array}{ll}\text { Tide } & \\
\text { Wind } \quad \text { (real } \\
\text { values) }\end{array}$ & $\begin{array}{l}\text { Orfila et al. } \\
(2005)\end{array}$ \\
\hline $\begin{array}{l}\text { To describe the physics of the bay, to understand the water } \\
\text { mass movements and exchanges between the bay and its } \\
\text { frontiers by assessing age, flushing time and residence time. }\end{array}$ & $\begin{array}{l}\text { 2D model } \\
\text { Eulerian }\end{array}$ & $\begin{array}{l}\text { Arcachon } \\
\text { (France) }\end{array}$ & $\begin{array}{l}\text { Tide } \\
\text { Wind } \\
\text { River flow } \\
\text { (scenarios) } \\
\end{array}$ & $\begin{array}{lll}\text { Plus et al. } \\
(2009)\end{array}$ \\
\hline $\begin{array}{l}\text { To determine water renewal pathways and to assess regional } \\
\text { differences in renewal time scales. }\end{array}$ & \begin{tabular}{ll|} 
BD & model \\
Eulerian
\end{tabular} & $\begin{array}{l}\text { Hervey } \\
\text { (Australia) }\end{array}$ & $\begin{array}{l}\text { Tide } \\
\text { Wind } \\
\text { (scenarios) }\end{array}$ & $\begin{array}{l}\text { Ribbe et al. } \\
(2008)\end{array}$ \\
\hline $\begin{array}{l}\text { To evaluate, within a comparative framework, the spatial } \\
\text { patterns of residence times in bays with varying size, coastline } \\
\text { geometry, and exchange capacity with the ocean, to investigate } \\
\text { the controls on bay-to-bay differences in residence time, and to } \\
\text { quantify exchange among these bays. }\end{array}$ & $\begin{array}{l}\text { 3D model } \\
\text { Lagrangian }\end{array}$ & $\begin{array}{l}\text { Virginia coast, } 9 \\
\text { bays (USA) }\end{array}$ & $\begin{array}{l}\text { Tide } \\
\text { Wind } \quad \text { (real } \\
\text { values) }\end{array}$ & $\begin{array}{l}\text { Safak et al. } \\
(2015)\end{array}$ \\
\hline
\end{tabular}




\begin{tabular}{|c|c|c|c|c|}
\hline $\begin{array}{l}\text { To investigate the influences of hydrological conditions, } \\
\text { surface wind stress, and density-induced circulation on the } \\
\text { transport timescale of dissolved substances. }\end{array}$ & \begin{tabular}{|lr} 
3D model & \\
Eulerian & (tracer \\
and & age \\
equations) & \\
\end{tabular} & $\begin{array}{l}\text { Chesapeake bay } \\
\text { (USA) }\end{array}$ & $\begin{array}{l}\text { Tide } \\
\text { Wind } \\
\text { River flow } \\
\text { (scenarios) }\end{array}$ & $\begin{array}{l}\text { Shen and Wang } \\
(2007)\end{array}$ \\
\hline $\begin{array}{l}\text { To investigate the potential of numerical modelling to } \\
\text { understand the hydrodynamics of the lagoon and the role of } \\
\text { various flow forcing and estimate the residence time with a } \\
\text { high spatial resolution. }\end{array}$ & $\begin{array}{l}\text { 3D model } \\
\text { Lagrangian }\end{array}$ & $\begin{array}{l}\text { Mururoa } \\
\text { (France) }\end{array}$ & $\begin{array}{l}\text { Wind } \\
\text { (scenarios) } \\
\text { Tide }\end{array}$ & $\begin{array}{l}\text { Tartinville et al. } \\
\text { (1997) }\end{array}$ \\
\hline $\begin{array}{l}\text { To calibrate, integrate and validate a model of vertical } \\
\text { swimming for the bivalve larvae. } \\
\text { To validate the transport model integrating the swimming sub- } \\
\text { model with data acquired in situ. } \\
\text { To evaluate the intra-lagoonal connectivity patterns and } \\
\text { quantify exchanges between potential sink and source sectors. } \\
\text { To discuss the consequences of larval dispersal on pearl oyster } \\
\text { settlement variability and aquaculture management }\end{array}$ & $\begin{array}{l}\text { 3D model } \\
\text { Eulerian } \\
\text { Connectivity } \\
\text { matrix }\end{array}$ & $\begin{array}{l}\text { Ahe } \\
\text { (France) }\end{array}$ & $\begin{array}{l}\text { Wind } \\
\text { Tide } \\
\text { Wind } \\
\text { (scenarios) }\end{array}$ & $\begin{array}{l}\text { Thomas et al. } \\
(2012)\end{array}$ \\
\hline $\begin{array}{l}\text { To interpret tidal mixing by using Markov Chain theory. } \\
\text { To present a procedure to estimate transition probabilities from } \\
\text { the trajectories of particles simulated using a realistic tidal } \\
\text { model. } \\
\text { To quantify the retention and exchange properties. } \\
\text { To compare predictions from the Markov Chain against the } \\
\text { trajectories of } 105 \text { particles calculated from the model's tidal } \\
\text { flow fields. }\end{array}$ & $\begin{array}{l}\text { 2D model } \\
\text { Lagrangian }\end{array}$ & $\begin{array}{l}\text { Passamaquody bay } \\
\text { (Canada) }\end{array}$ & Tide & $\begin{array}{l}\text { Thompson et al. } \\
(2002)\end{array}$ \\
\hline $\begin{array}{l}\text { To test the statistical relationships between the distribution of } \\
\text { flushing indices determined on an array of stations in the } \\
\text { lagoon and the distribution of biological and chemical } \\
\text { variables acquired during three oceanographic campaigns in } \\
\text { the same lagoon }\end{array}$ & $\begin{array}{l}\text { 3D model } \\
\text { Eulerian }\end{array}$ & $\begin{array}{l}\text { Southwest lagoon } \\
\text { (New-Caledonia) }\end{array}$ & $\begin{array}{l}\text { Wind } \\
\text { (scenarios) } \\
\text { Tide }\end{array}$ & $\begin{array}{l}\text { Torréton et al. } \\
(2007)\end{array}$ \\
\hline $\begin{array}{l}\text { To estimate connectivity between islands across the Tropical } \\
\text { Pacific }\end{array}$ & $\begin{array}{l}\text { 2D model } \\
\text { Eulerian } \\
\text { Connectivity } \\
\text { analysis (graph } \\
\text { theory) }\end{array}$ & $\begin{array}{l}\text { Pacific } \\
\text { (islands) }\end{array}$ & $\begin{array}{ll}\text { Wind } & \text { (real } \\
\text { values) } & \end{array}$ & $\begin{array}{l}\text { Treml et al. } \\
(2008)\end{array}$ \\
\hline $\begin{array}{l}\text { To compare lagoons using computed parameters for lagoons } \\
\text { classification : fluxes, water renewal time, water flushing time, } \\
\text { mixing efficiency }\end{array}$ & $\begin{array}{l}\text { 3D model } \\
\text { Eulerian }\end{array}$ & $\begin{array}{l}10 \text { Mediterranean } \\
\text { lagoons }\end{array}$ & $\begin{array}{l}\text { Tide } \\
\text { River runoffs } \\
\text { Wind (real } \\
\text { values) }\end{array}$ & $\begin{array}{l}\text { Umgiesser et al. } \\
(2014)\end{array}$ \\
\hline $\begin{array}{l}\text { To compare calculations of residence times for individual } \\
\text { parcels (based on Lagrangian tracking) with estimates based on } \\
\text { volume and salt budgets. }\end{array}$ & $\begin{array}{l}\text { 2D model } \\
\text { Lagrangian }\end{array}$ & $\begin{array}{ll}\text { Puttalam lagoon } \\
\text { (Sri Lanka) }\end{array}$ & $\begin{array}{l}\text { Tide } \\
\text { Wind } \\
\text { River flow } \\
\text { (scenarios) }\end{array}$ & $\begin{array}{l}\text { Wijeratne and } \\
\text { Rydberg (2007) }\end{array}$ \\
\hline $\begin{array}{l}\text { To better understand the distribution of the residence time of } \\
\text { Passive Dissolved Conservative Matter. }\end{array}$ & $\begin{array}{l}\text { 2D model } \\
\text { Eulerian }\end{array}$ & $\begin{array}{ll}\text { Mersey } & \text { estuary } \\
\text { (England) } & \end{array}$ & $\begin{array}{l}\text { Tide } \\
\text { River flow } \\
\text { (scenarios) }\end{array}$ & $\begin{array}{l}\text { Yuan et al. } \\
(2007)\end{array}$ \\
\hline
\end{tabular}

Table 2. Review of recent works on connectivity and residence time assessments. 


\section{List of Tables and Figures}

Table 1. Main characteristics of the 3 study sites

Table 2. Review of recent works on connectivity and residence time assessments.

Figure 1. Study sites

Figure 2. Comparison of Hydrodynamic and Averaged-Flow model results

Figure 3. Distribution of mean (RMS) currents in the three systems

Figure 4. Comparison of water renewal time (hydrodynamic model) and water residence time (Markov chains)

Figure 5. Example of transfer rate and transfer time from grid cell marked in red

Figure 6. Maximum transfer rate and minimum transfer time from aquaculture leases to the rest of the system 


\section{Appendix A. Volumetric flow calculation (adapted from Filgueira et al., 2012)}

The implementation of the RMA hydrodynamic model relies upon an unstructured grid made of triangular elements which accounts for the variability of the bathymetry and the morphology of each bay. Every node (vertex of each triangle) of the grid is represented with $\mathrm{X}$ and Y Cartesian coordinates. For each node, RMA provides values for three quantities at each time step: water speed in the x-direction, water speed in the $y$-direction and water depth. RMA stores the results in matrices that can be programmatically retrieved and manipulated. Each element (triangle) of an unstructured triangular grid can be surrounded by a maximum of 3 elements and a minimum of 1 element.

Current velocity has 2 components $(u, v)$ at the center of each side of a triangular element (link). $u$ is the average velocity in the $\mathrm{x}$-direction at the two ends of the link and $v$ is similarly defined for the y direction - both quantities are adjusted to meters per day. The net velocity $U$ is defined as the projection of the velocity vector into the unit perpendicular vector of the link $(n x, n y)$ with the equation:

\section{$U=n x \cdot u+n y \cdot v$}

The unit perpendicular vector $(n x, n y)$ is defined to point towards the center of the element (Fig. A.1). Therefore a positive/negative net velocity indicates that flow is into/out of the element.

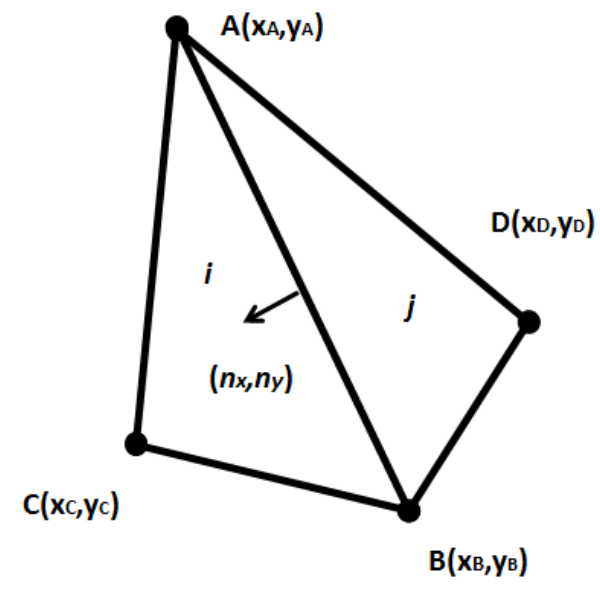

Figure A.1. Structure of element $i$ defined by the nodes A(xA,yA), $\mathrm{B}(\mathrm{xв}, \mathrm{yB})$ and $\mathrm{C}(\mathrm{xс}, \mathrm{yc})$ and vectors used to calculate the flow through the link A-B between elements $i$ and $j$. Vector $\left(n_{x}, n_{y}\right)$ originates at the bisection of link A-B and is oriented perpendicular to A-B towards the interior of element $i$ to compute the directional inflow to or outflow from $i$. 
The exchange of water between two elements is defined in relation to each of the surrounding elements in the grid in terms of volumetric exchange. The volumetric flow $F\left(\mathrm{~m}^{3} \mathrm{~d}^{-1}\right)$ through a link from one element to another is calculated by multiplying the net velocity $U\left(\mathrm{~m} \mathrm{~d}^{-1}\right)$ by the cross-sectional area $S\left(\mathrm{~m}^{2}\right)$ through the side:

$F=U \cdot S$

where $S$ is equal to the average depth at the two nodes of the link multiplied by the distance between the 2 nodes (length of the link).

RMA provides a time series for water velocity and depth at each node, and the protocol described above can be applied to each time step. The volumetric flows for all time steps are averaged over a whole neap/spring tidal cycle for each link. The averaging procedure is directional, which means that the calculation provides the inflow and outflow between each pair of elements defined in the computation grid. After this process, the average volume $\left(\mathrm{m}^{3}\right)$ of each element and the average volumetric bidirectional flows $\left(\mathrm{m}^{3} \mathrm{~d}^{-1}\right)$ between every pair of adjacent elements are used to define the average circulation of the bay (Filgueira et al., 2012). As a result flows represent stationary (constant) exchanges between pairs of elements, and these exchanges are asymmetrical (the inflow is not necessarily equal to the outflow). We have also checked that the mass conservation principle is not violated.

\section{References}

Filgueira, R., Grant, J., Bacher, C., Carreau, M., 2012. A physical biochemical coupling scheme for modeling marine coastal ecosystems. Ecol. Inform. 7, 71-80. 


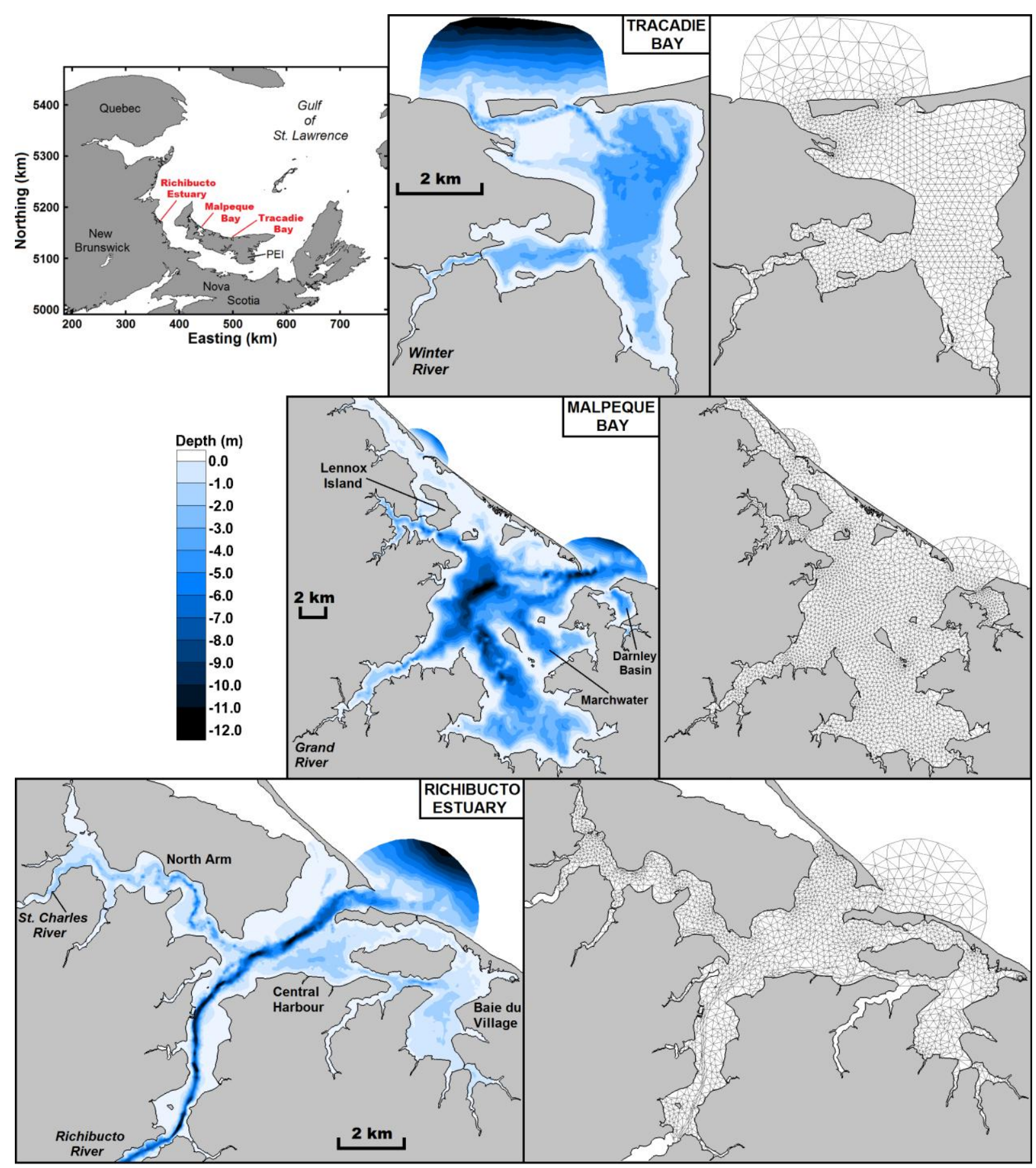

Figure 1 

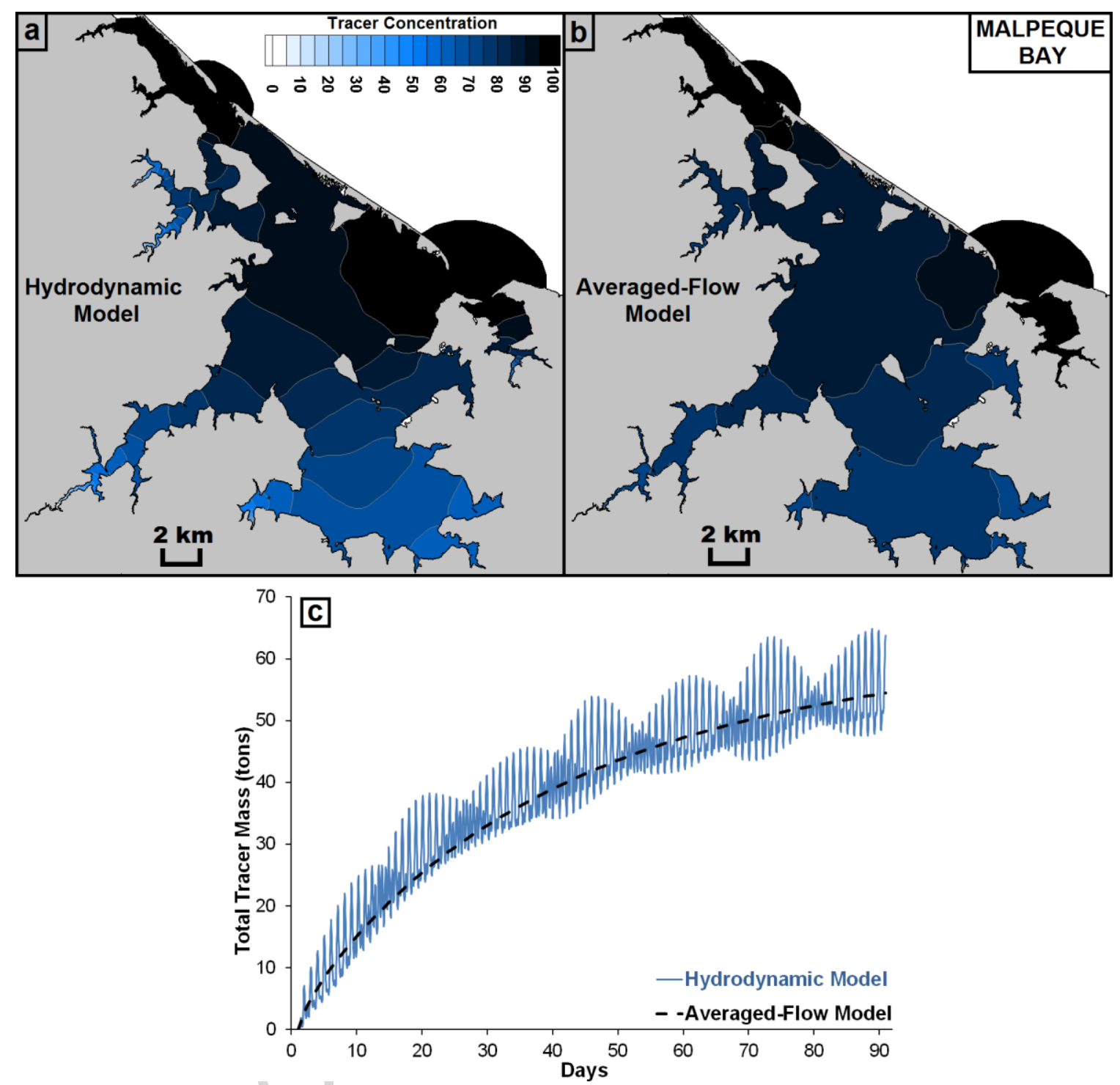

Figure 2 


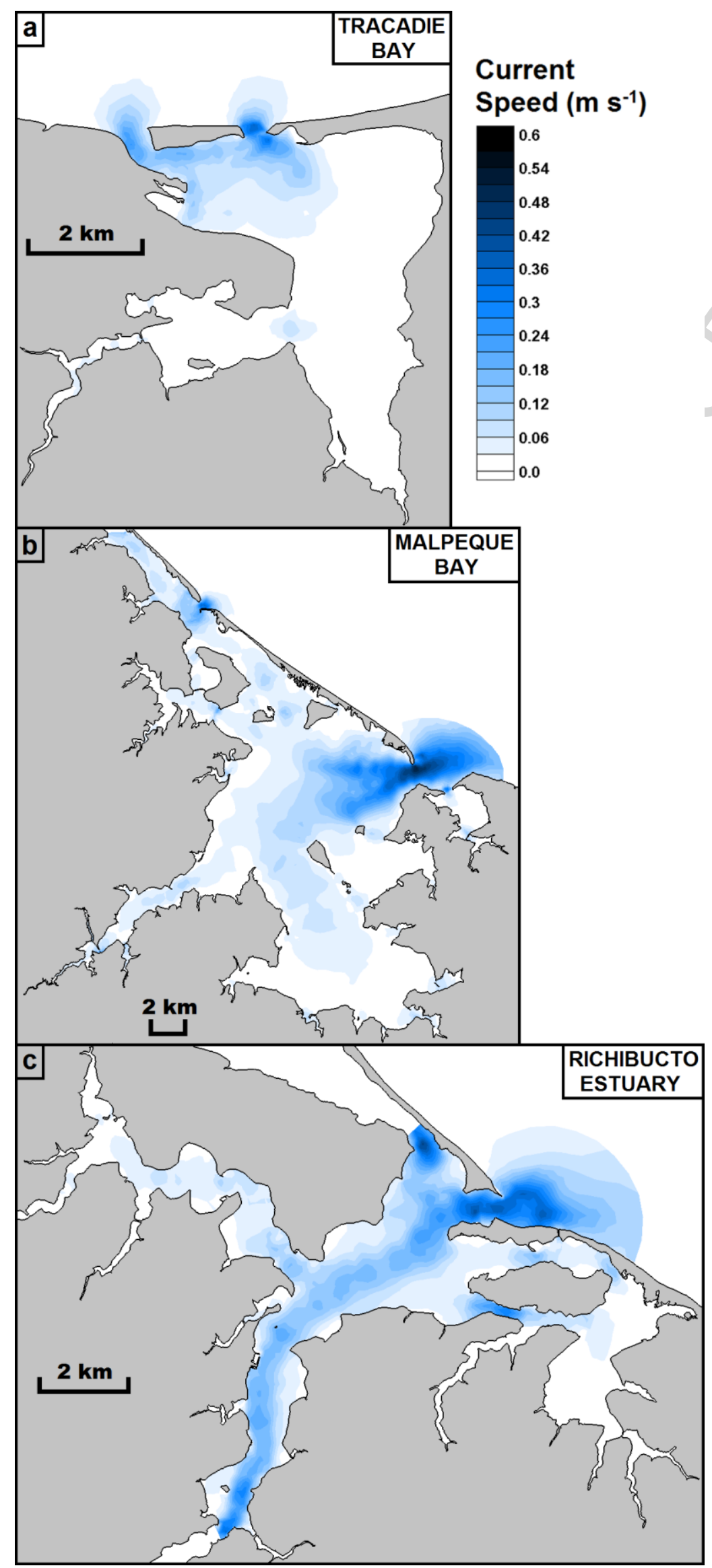

Figure 3 


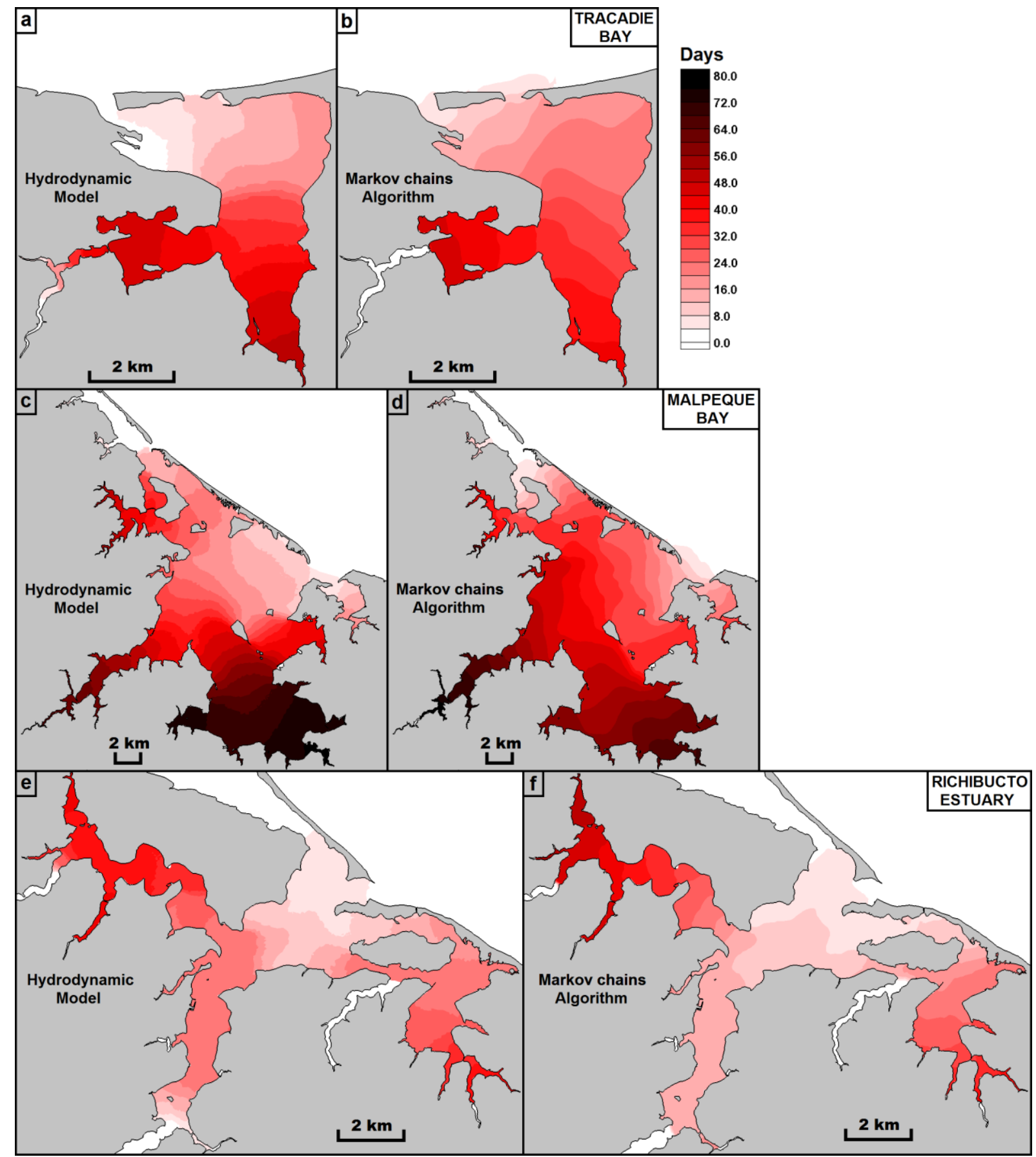

Figure 4 


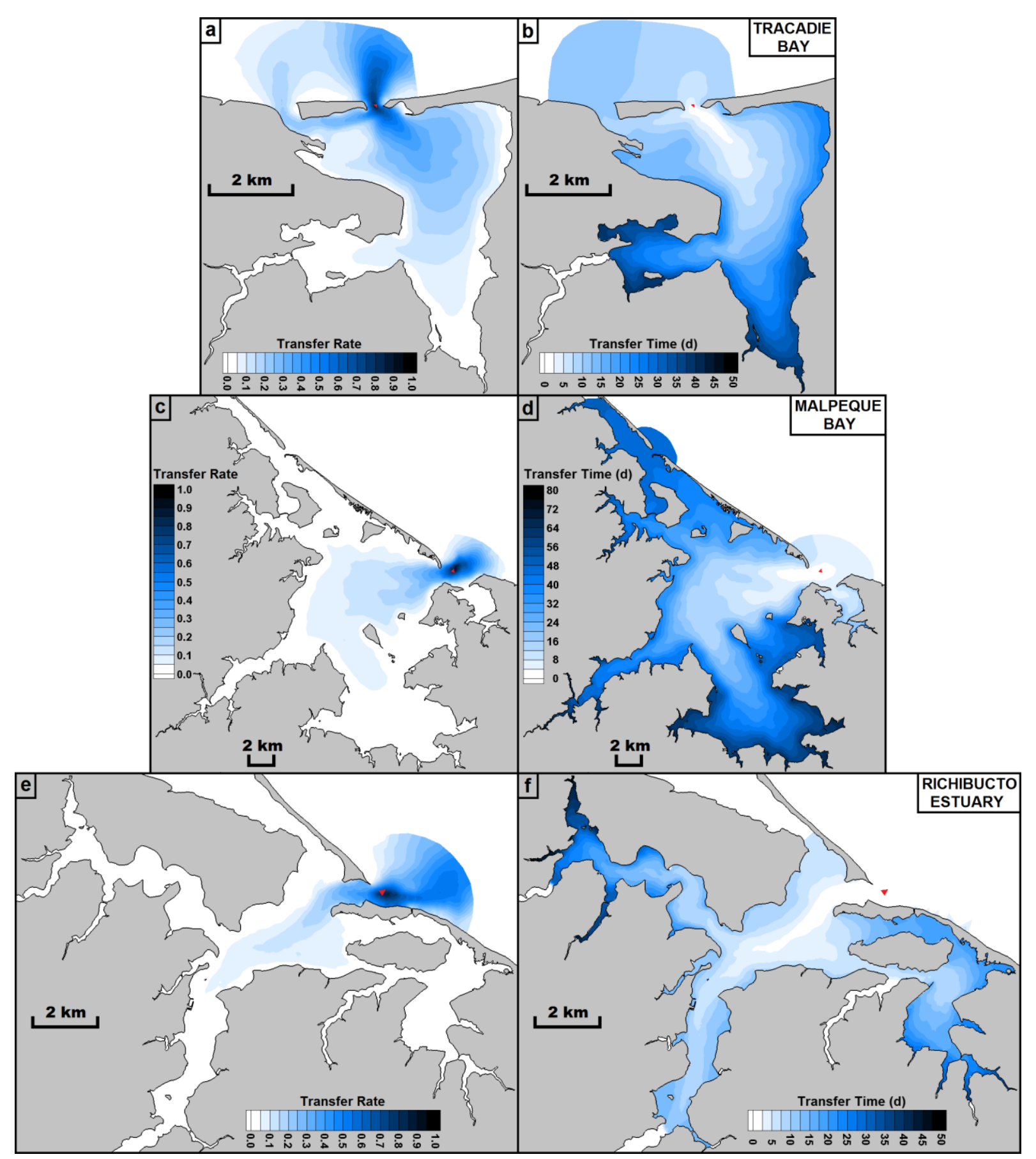

Figure 5 


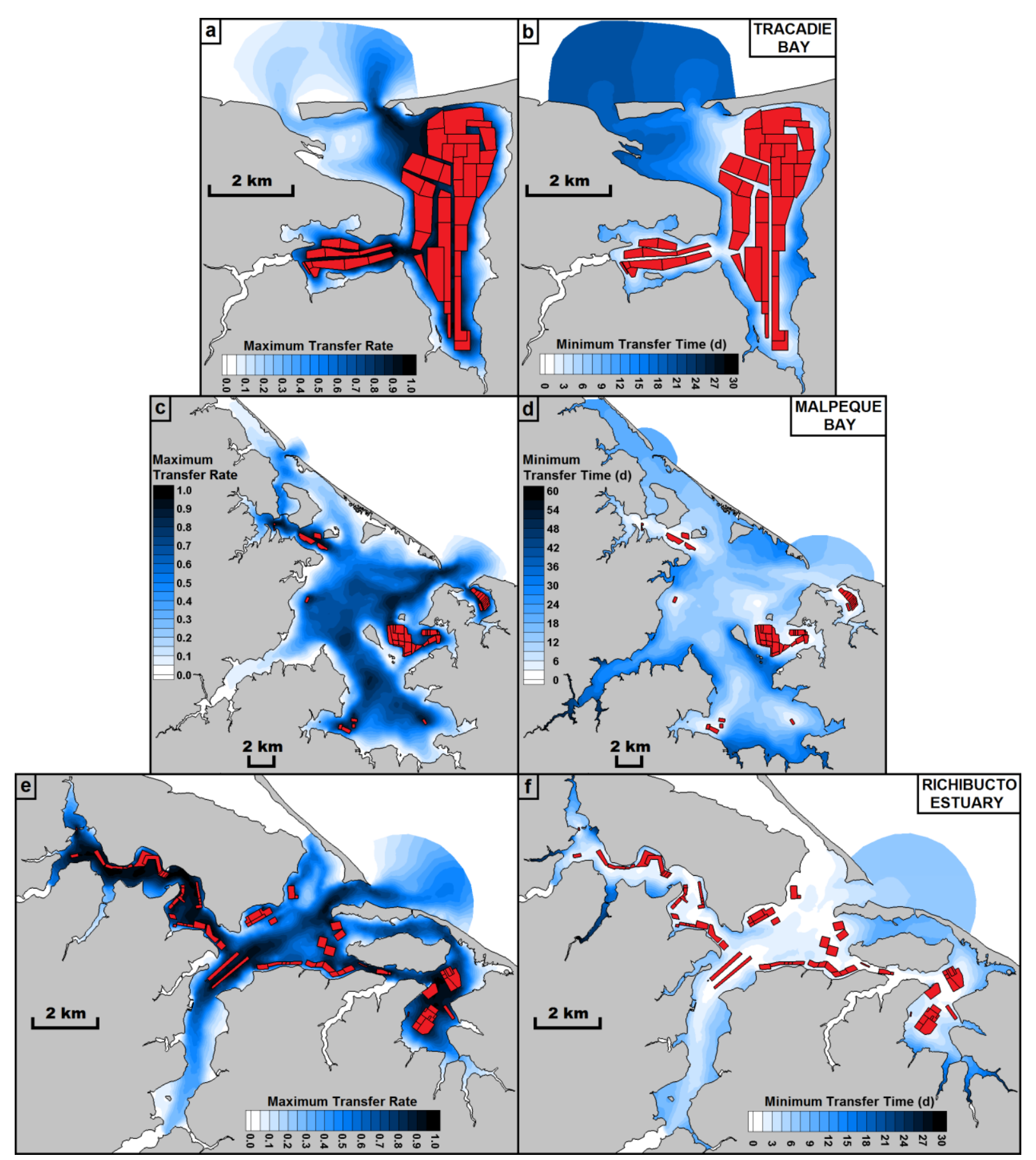

Figure 6 